\title{
GLASS VESSELS FROM LATE ROMAN TIMES FOUND IN PANNONIA
}

\author{
KATA DÉVAI \\ MTA-ELTE Research Group for Interdisciplinary Archaeology \\ Eötvös Loránd University \\ H-1088 Budapest, Múzeum krt. 4/B, Hungary \\ kata.devai@gmail.com
}

\begin{abstract}
The period between the beginning of the $4^{\text {th }}$ century and the middle of the $5^{\text {th }}$ century AD is the peak of glass production in Pannonia: there is a significant amount of very colourful and diverse glass finds, and there are whole series of vessels. This study is based on the typological classification of about 1000 glass finds. From the second half of the $4^{\text {th }}$ century AD two regions can be highlighted with regard to the geographical distribution of glass vessels. The stretch of the limes between Arrabona and Intercisa, within the area of which the Danube Bend was the most remarkable one, as more than half of the vessels (53\%) were found in this region. The other zone was the city of Sopianae and its vicinity, where $20 \%$ of the studied glass finds were found.

Keywords: Late Roman Pannonia, cemeteries, glass vessels, glass production
\end{abstract}

This study is based on the results of my doctoral thesis defended in 2013. ${ }^{1}$ The main goal of the dissertation was to present Late Roman glass vessels found in graves in the Hungarian part of Pannonia. In addition, the dissertation also contained a typology based on the colours of the various glass vessels, the quality of their materials, their decorations, and other details, all of which have yet to be assessed in Hungarian research. The secondary goal was to analyse the chronological and geographical diversity of glass types, in other words how glass objects were used, how individual workshops defined geographical areas. There are thousands of graves in Pannonia from the Late Roman Period, in which several glass artefacts were found. ${ }^{2}$ For the purposes of this dissertation only graves found within the geographical area of present day Hungary have been considered, from Pannonia Prima and Valeria provinces (Fig 8). Chronologically, the dissertation focused on the period between the beginning of the $4^{\text {th }}$ century and the middle of the $5^{\text {th }}$ century AD. The surrender of Pannonia is not considered the end date because the production of Roman-type glass likely continued into the $5^{\text {th }}$ century AD.

The study has three principal aims. First, it aims to define the areas that had an impact on glass-making in Pannonia. Second, it defines the volume of imported goods and local manufacturing within the boundaries of the province. Third, it compares how glass was used in various territories with differing attributes and characteristics.

It is essential to highlight the differences in both quality and quantity of glass vessels found near the Danube Bend along the limes, and in the urban settlements in the interior of the province. In the late Roman period, the areas along the limes played a significant role due to the Barbarian attacks along the borders of the Empire. Since the provision of troops was the responsibility of the empire, large numbers of glass vessels were used on these military

${ }^{1} \mathrm{PhD}$ thesis submited in 2013 to the Archaeology Doctoral Programme, Doctoral School of History, Eötvös Loránd University, Budapest under the supervision of László Borhy. Hereby I would like to express my gratitude to Alice Choyke for proofreading my paper and also László Rupnik for designing my maps.
${ }^{2}$ LÁNYI 1972, 64-213; TOPÁl 1993; TOPÁL 2003; BARKÓCZI 1960; BARKóCZI 1968; FÜlEP 1984; FÜlEP 1977; BURGER 1966; Burger 1968; BARKóczi-SAlAmon 1970; Burger 1972; Burger 1974; BuRGER 1979; VÁGÓ-BÓNA 1976; SZIRMAI 1975; SZŐNYI 1979; PÉTERFI 1993; ZsIDI 1984; KELEMEN 2008. 
settlements. Similarly, glass objects were frequently used in both cities and villas of importance, while the usage of glass vessels dramatically decreased in the countryside Sopianae's role must be emphasised as it was the source of a remarkable variety of glass objects, which were known throughout the province for their quality, form, and decoration. Glass manufacturing flourished when the area became the centre of Valeria, which also resulted in a significant economic upswing for Sopianae and its surrounding area in the late Roman period.

The relationship between glass production and economic and historical changes in Pannonia was previously analysed by László Barkóczi who grouped the vessels into five periods, of which the last three $(\mathrm{B}, \mathrm{C}, \mathrm{D})$ are covered in this article. ${ }^{3} \mathrm{~L}$. Barkóczi's catalogue cannot be considered complete, although it includes 556 artefacts. ${ }^{4}$ His analysis focused only on intact vessels, although examination of fragmented objects is also important. In addition, the 556 finds span the entire historical period of Pannonia, whilst my dissertation examines 987 objects exclusively from the $4^{\text {th }}$ and $5^{\text {th }}$ centuries $\mathrm{AD}$ (Fig. 8). This means that the present study focuses on a narrower period while basing its findings on a greater number of objects.

The era in question represents the peak period of glass production in Pannonia. A remarkable number of vessels were manufactured, including whole series of each type, which were both colourful and diverse. ${ }^{5}$ Because of this characteristic, they provided perfect subjects for analysis. Beginning at the end of the $3^{\text {rd }}$ century AD, larger and more practically shaped vessels spread across the province. Between the end of the $3^{\text {rd }}$ century and the end of the $5^{\text {th }}$ century AD numerous stylistic differences appeared. The description and analysis of these stylistic elements are two of the main goals of this paper. At the end of the $3^{\text {rd }}$ century AD, large numbers of utilitarian glass vessels appeared, which were varied in both height and function. Tall cups, flasks, and jugs dominated in this period, while storage and transport vessels, as well as unguentariae were less popular. High quality raw materials were used for these colourless glass vessels. Clear, colourless glass remained the preferred shade until the end of the $4^{\text {th }}$ century AD. For the most part the forms were simple and sophisticated, and incorporated little decoration. Only a small number of these vessels were refined or elaborately decorated. This suggests that every household had easy access to glass products during this period. ${ }^{6}$ They were not considered luxury items but rather everyday objects meant for daily use. In the middle of the $4^{\text {th }}$ century $\mathrm{AD}$ a fundamental shift occurred which changed the popular shapes of vessels and gave rise to different combinations of new embellishments. ${ }^{7}$ The quality and colour of the raw materials changed. Smaller numbers of a range of colourless vessels made of good quality raw materials continued to be made until the end of the $4^{\text {th }}$ century and until the beginning of the $5^{\text {th }}$ century $\mathrm{AD} .{ }^{8}$ However, the vast majority of the objects, mostly tableware and unguentariae, were made using poor quality materials and featured dark specks and tiny bubbles in shades varying from dark green, to moss green, to yellowish green. ${ }^{9}$ Within the province it is worth considering both regional and formal differences between vessels when contrasting the two prominent raw materials used: the colourless, good quality raw materials and the dark greenish, bad quality ones. The process of shaping the objects changed as certain parts were no longer thoroughly wrought, and polished cutting-edged rims were converted into unpolished and coarse edges. One of the reasons for these changes may lie the decrease in demand for high quality objects because a growing number of the settling foederati preferred vessels characterized by different looks. This also suggests a change in trade relations within the province. Poor quality raw materials were likely purchased from new, alternative sources when the colourless, good quality glass was either no longer available or was for obtainable only for unreasonable prices. ${ }^{10}$ The spread of the poor quality materials does not prove that raw glass was manufactured within the borders of the province. This type of glass appeared in other provinces in the late Roman period, and a prominent workshop in Egypt was well known for producing similar tones of glass, the so-called HIMT glass, which contained large quantities of metallic-oxides. ${ }^{11}$ Presumably, this shade was the result of using bad quality, less pure sand with a higher metallic oxide component. The existence of glass marked by bubbles does not reflect decline of technical standards starting in the second half of the $4^{\text {th }}$ century AD. Rather it indicated that the melting process of the materials was less time-consuming, which in turn needed less fuel and

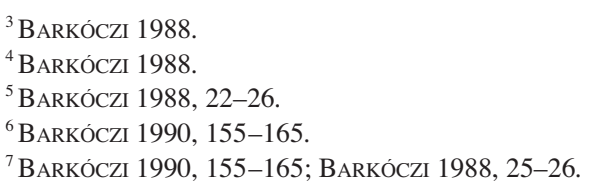

${ }^{8}$ DÉVAI 2012.

${ }^{9}$ DÉVAI 2012.

${ }^{10}$ DÉVAI 2012, 245

${ }^{11}$ FREESTONE-GREENWOOD-GoRIN-Rosen 2002, 167-172; HARTMANN-GRÜNEWALD 2010, 15; SAGUí 2007, 215. 
was less expensive. The raw material of these objects was cost effective because the bubbles would have increased their volume.

The typological classification of about 1000 glass finds (Fig. 8) comprising the main results of the analysis, as well as the chronological and geographical backgrounds of the objects is summarized as follows. Mainly tableware was produced in the Late Roman period; $57.9 \%$ of the finds belong to this category. Within this group, drinking vessels dominate (45.5\% of the total) (Fig. 11). ${ }^{12}$ Bowls and dishes (A1) appear to have lost the importance they had in previous periods, as they were found only sporadically (2.2\% of the total) (Fig. 9). With regard to the distribution of bowls, no clear trends can be identified - they not only occur along the limes, but also in the province. Most bowls were found in Intercisa and Sopianae, but there are also a few pieces known from Aquincum, Brigetio, Keszthely, Mórichida-Kisárpás, Ságvár, Scarbantia, and Somogyszil. The ones from Aquincum and Brigetio were dated to the beginning of the $4^{\text {th }}$ century AD. The number of jugs (A3) (Fig. 4) - used mainly for serving liquids - is higher than the number of bowls (10.1\% of the total). ${ }^{13}$ As far as their geographical distribution is concerned (Fig. 16), they occur also along the limes and in larger cities (e.g. Solva, Intercisa, Sopianae, Aquincum, MórichidaKisárpás and, Ságvár). Among the storage and container vessels, only bottles (B1) are present in more significant numbers (20.2\% of the total). Their primary purpose was for storing liquids, which is indicated by the more closed shape of their mouths. ${ }^{14}$ They were found in large numbers in Aquincum, Brigetio, Solva, Intercisa, Pilismarót, Ságvár and, Sopianae Their distribution is concentrated in the Danube Bend and in the vicinity of Pécs. Only one or two pieces were recovered from other sites (Fig. 17) Jars used for food storage (B2) appear to have disappeared completely; only one example was recovered from a sarcophagus in Szekszárd. Unguentaria also occur less frequently in comparison to previous centuries, although they remain fairly common in late Roman times (18.8\% of the total number of finds) (Fig. 6-7). ${ }^{15}$ They were typically found in graves and date to before the end of the $4^{\text {th }}$ century AD. Often more than one unguentaria were placed in a grave in the early Roman period, while in the late Roman period a single perfume bottle in each grave was more typical. ${ }^{16 \mathrm{~A}}$ A greater number of Unguentaria were found in Sopianae, Brigetio, around Solva, Aquincum, Bátaszék-Kövesd, Intercisa and, Ságvár (Fig. 18). The miscellaneous category (E) includes objects that could not be classified into any of the above types, such as flasks for dripping with globular body ("Flasche mit kuglischem Körper und Ausgusstülle") ${ }^{16 \mathrm{~B}}$ and vasa diatreta (the function of which is debated). This group makes up $2.5 \%$ of the total. ${ }^{17}$

In summary, beakers or drinking vessels were the most commonly used vessels, while bottles were less frequently encountered and jugs were quite unusual. Jars disappeared entirely. The use of unguentariae was common until the end of the $4^{\text {th }}$ century AD. Using these same categories, no remarkable deviations between urban settlements and settlements along the limes can be observed. That said, there are notable differences in how glass vessels were used between villas and vici compared to urban settlements inside the province and along the limes because goods could not be conveyed to those areas that were located far away from the main trading routes in Pannonia in the $4^{\text {th }}$ century AD. Most glass vessels (more than $75 \%$ ) can be traced to two regions: the zone between Arrabona and Intercisa, and the area of South-Valeria, particularly the region of Sopianae (Fig. 8).

Based on the classification and analysis of functional categories we can conclude that there was an important increase in the proportion percentage of category A2. This is followed by category A3 (jugs), whereas the number of bowls (A1) diminished significantly.

According to S. M. E. van Lith and K. Randsborg, any divergence from these tendencies in the late Roman period reflects the different economic conditions of the settlements. ${ }^{18}$ In Pannonia, there is no such divergence whatsoever and occurrence-ratios remain consistent throughout the province. A vast number of vessels came to light in Ságvár, in Sopianae and surrounding areas, as well as at the sites situated around the Danube Bend, especially in Solva. Ságvár is the only outlier. Here, the number of cups is not especially high, but is, in fact, lower than finds in other categories.

\footnotetext{
${ }^{12}$ DÉval 2012, 33.

${ }^{13}$ DÉVAI 2012, 36-37.

${ }^{14}$ DÉVAi 2012, 39-40.

${ }^{15}$ DÉVAI 2012, 42-43.
}

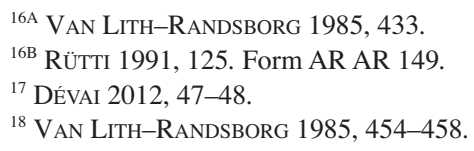




\section{TYPOLOGY}

Since the 1990s, the general typology of Roman glass objects has been based on their function. According to S. M. E. van Lith and K. Randsborg, glass vessels could be classified into three basic groups, within which six subgroups were defined. ${ }^{19}$ However, classifying glass vessels by only studying their shape does not provide sufficient information. The analysis of production techniques, colours, and materials is equally important. Glass production in Pannonia was previously analysed in an economic and historical context by L. Barkóczi, who applied a chronological classification system consisting of five periods, of which only the last three ones (B, C, D) were considered in this article. ${ }^{20}$ Barkóczi's catalogue was, however, incomplete. Although he covered the whole period and included 556 vessels, he analysed only the intact ones. Nevertheless, studying fragments is also important, and this dissertation altogether 987 objects were evaluated covering only the $4^{\text {th }}$ and $5^{\text {th }}$ centuries AD.

In order to classify the vessels studying only their shape is insufficient. Hence the analysis of the production techniques, their colours, the quality of their materials and the forming of the different parts of the vessels becomes unavoidable. Unfortunately, a terminology of glass objects in Hungary has not yet been provided. For this reason a new typology for the specific area and time period was needed. To establish the new typology I have used works written by B. Rütti, H. M. E. Cool and J. Price, I. Lazar, G. Harter, C. Isings, S. Cottam and J. Price, and S. Jennings. ${ }^{21}$

Based on this comprehensive database, a new typological system was created, with five basic categories. Although it follows the functional grouping applied by S. M. E. van Lith and K. Randsborg, ${ }^{22}$ their existing categories were renamed. The basic types were marked with the first initials of their Hungarian names as follows (Figs 1-7): A1 : bowl > tál > T; A2 : cup > pohár > P; A3 : jug > korsó $>\mathrm{K}$; B1: bottle > palack > Pa; B2 : jar > fazék > F; C: unguentarium $>$ illatszeres $>$ I. Those fragments which could not be classified into any of these categories were considered as miscellaneous (egyéb > E), as used by I. Lazar and G. Harther. These types were broken down into variations sub-groups - marked with numbers, indicating whether the vessels are decorated or not. Variant Nr. 1 stands for undecorated vessels; variant Nr. 2 for decorated ones. Sometimes different types of decorations appear on the same vessel. This classification system allows the combination of decorations to be studied as well. The last elements of the typological system are the A and B variants, which refer to different aspects of an object's shape and form. In case of bowls, cups, jars, bottles and perfume holders variant A means that their rims were cracked-off, while variant B marks fire-rounded rims. In the case of jugs, the rims were always fire-rounded, so variant A and B refer to differences in the elaboration of the base.

\section{Bowls}

The most typical bowl was the shallow convex bowl (T 1) (Fig. 1, Fig. 9), which could be decorated with wheel-cut lines or abrasion bands. ${ }^{23}$ Convex bowls with indents also appeared sporadically (T 2) (Fig. 1). ${ }^{24}$ The third type was the shell-shaped, mould-blown bowl (T 3) (Fig. 1, Fig 10). ${ }^{25}$ In addition, there is one round plate decorated with concentric circles at its base (T 4) (Fig. 1). ${ }^{26}$ The final category of bowls is represented by a single wide, round and thickplate with facet-cutting (T 5) (Fig. 1). ${ }^{27}$ The first three types were typical in the second half of the $4^{\text {th }}$ century $\mathrm{AD}$, and may have also existed at the beginning of the $5^{\text {th }}$ century $\mathrm{AD}$. The last two types are dated to the beginning of the $4^{\text {th }}$ century AD.

\author{
${ }^{19}$ VAN LiTH-RANDSBORG 1985. \\ ${ }^{20}$ BARKÓCZI 1988. \\ ${ }^{21}$ RÜTTI 1991; CoOL-Price 1995; IsIngs 1957; CotTAM- \\ PRICE 1998; JenNings 2004-2005; LAZAR 2004; HARTER 1999. \\ ${ }^{22}$ VAN LITH-RANDSBORG 1985. \\ ${ }^{23}$ BARKóCZI 1988, Form 13; RÜTTI 1991, Form 56; \\ GOETHERT-PolascheK 1977, Form 27b; LAZAR 2003, Form 2.6.1; \\ CotTAM-Price 1998, Fig. 51.
}

${ }^{24}$ BARKÓCZI 1988, Form 17; IsINGS 1957, Form 116b/117; RÜtTI 1991, Form 59.2; Goethert-PolascheK 1977, Form 15b; Lazar 2003, Form 2.6.5; CotTAM-Price 1998, Fig.52.

${ }^{25}$ STERN 1995, Cat. 137; BARKÓCZI 1988, Form 189.

${ }^{26}$ BARKócZi 1988, Form 10; Vessberg 1952, Taf. 1.6

${ }^{27}$ BARKÓCZI 1988, Kat. 49. 


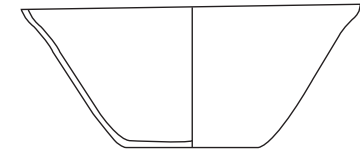

$\mathrm{T} 1.1 \mathrm{~A}$

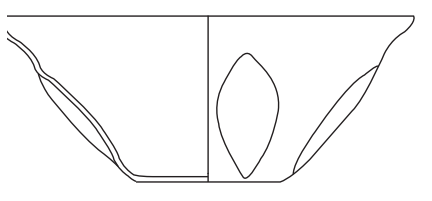

$\mathrm{T} 2.1 \mathrm{~A}$

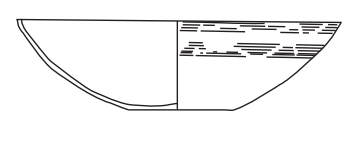

T1.2A

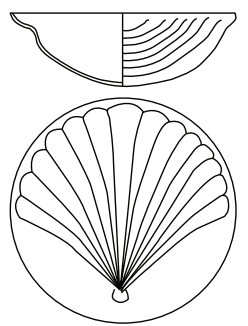

T3.2A
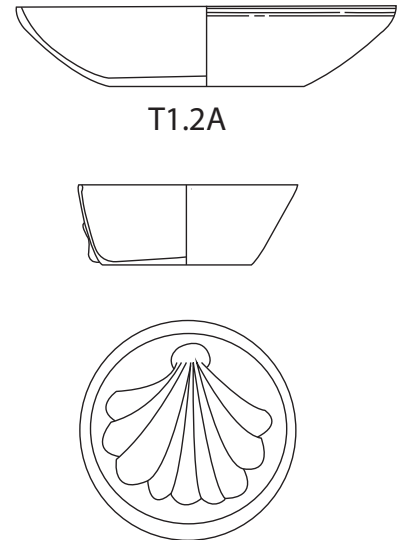

T3.2B

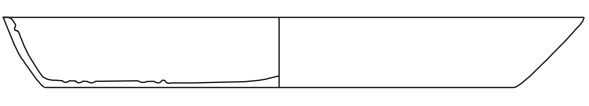

T4.2B

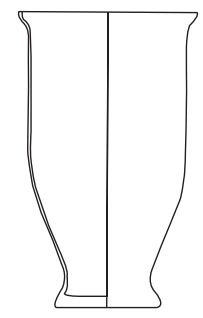

P1.1A

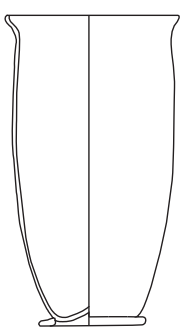

P2.1A

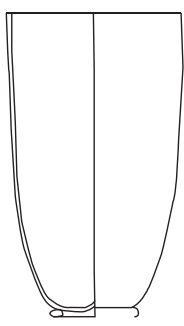

P4.1A

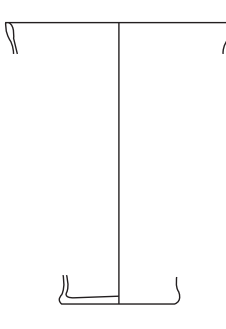

P1.1B

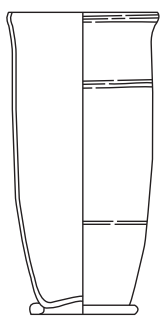

P2.2A

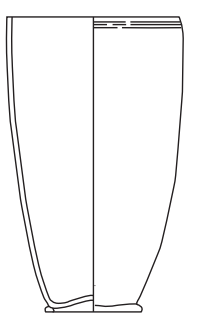

P4.1B

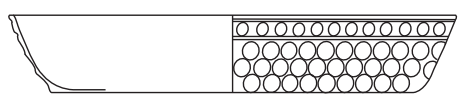

T5.2A

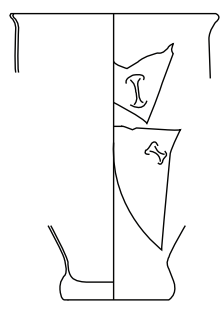

P1.2A

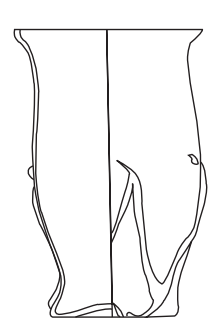

P1.2A

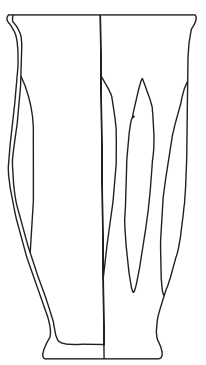

P1.2A

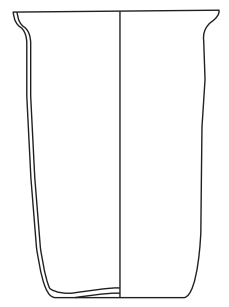

P3.1A

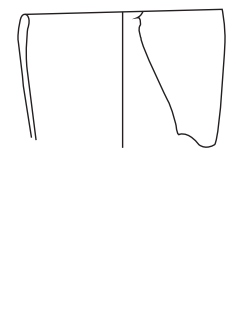

P3.1B

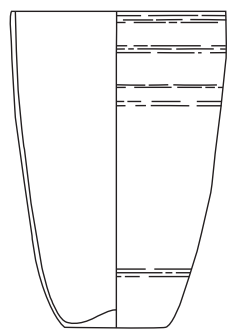

P3.2A

Fig. 1. Types of bowls and cups in late Roman Pannonia 


\section{Beakers and cups}

The most common glass burial finds from the late Roman period were beakers (Figs 1-3). Altogether, 453 vessels out of 987 are beakers, so nearly half the glass finds belong to this group. These beakers were of good quality and were made mainly of colourless or naturally coloured glass until the last third of the $4^{\text {th }}$ century AD. By the end of the $4^{\text {th }}$ century $\mathrm{AD}$, and in the $5^{\text {th }}$ century $\mathrm{AD}$ the dominant colours became moss green and strong yellow/ green tones, and the quality of the raw materials deteriorated, leading to vessels full of bubbles and strains. Crackedoff rims were formed and polished from the beginning of the $4^{\text {th }}$ century AD, although sometimes the cracked-off rims were left rough, a method that became more and more popular towards the end of the century. ${ }^{28}$

Slim beakers with curved bodies (P 1) (Fig. 1), ${ }^{29}$ slim beakers with curved walls and base rings (P 2) (Fig. 1) ${ }^{30}$ slim, cylindrical beakers (P 3) (Fig. 1), ${ }^{31}$ and slim, cylindrical beakers with base rings (P 4) (Fig. 1) $)^{32}$ can be associated with the same workshop based on similarities in quality, colour, size, embellishment, rims, and their chronological and geographical spread (Fig. 12). The workshop may have been in operation by the end of the $3^{\text {rd }}$ century AD, or the first half of the $4^{\text {th }}$ century. During this short period of time these forms occurred mainly in the vicinity of Arrabona, Brigetio and Aquincum. In Pannonia hemispherical cups (P 5) (Figs 1-2), ${ }^{33}$ - widespread and popular throughout the Empire from the $4^{\text {th }}$ until the beginning of the $5^{\text {th }}$ century AD - were present in large numbers. In Pannonia, these beakers were made of colourless glass using good quality raw materials. They were partially decorated, sometimes included abrasion bands, and the rims were usually cracked-off and unpolished. This type was more typical in the first two-thirds of the $4^{\text {th }}$ century AD.

Hemispherical cups with base rings (P 6) (Fig. 2) $)^{34}$ were also popular between the first third of the $4^{\text {th }}$ century AD, and the AD 380s. Their geographical spread is similar to that of the previous beaker type (Fig. 13). One of the most common cup forms is the mould-blown convex cup with a curved rim ("half-egg-shaped") (P 7) (Fig. 2), ${ }^{35}$ of which 67 pieces were found in Pannonia (Fig. 14). They became popular from the middle of the $4^{\text {th }}$ century AD, when they were made of natural green and colourless glass, using high quality materials. They reached their peak of popularility at the end of the $4^{\text {th }}$ century and in the first half of the $5^{\text {th }} \mathrm{c}$. AD. Following the surrender of Pannonia they remained popular in the Carpathian Basin during the $5^{\text {th }} \mathrm{c}$. AD but were made out of lower quality materials in strong yellow/green colours. ${ }^{36}$ They were probably produced in Pannonia since the colour and quality of the raw materials, as well as the manufacturing process are identical to the ones used for optic-blowing, globular flasks, cylindrical and pear shaped jugs and the smaller unguentaria, all of which were found in large quantities in the area. ${ }^{37}$ Objects in the $\mathrm{P} 7$ category dating from the $5^{\text {th }}$ century AD may have been products of a surviving glass workshop, because their colour, form, quality, the shape of rims, and their embellishments were all similar to vessels from the end of the $4^{\text {th }}$ and beginning of the $5^{\text {th }}$ century AD. Conical beakers (P 8-10) (Figs 2-3, Fig. 15) made up $35 \%$ of the finds. However, conical beakers with base rings (P 8), ${ }^{38}$ occurred less frequently: there are 44 of them listed in the catalogue. They are often seen in the first third of the $4^{\text {th }}$ century AD, and at the end of the century. Conical beakers with flat bases (P 9) are the most numerous (138 pieces), ${ }^{39}$ and more than half of them are undecorated. Most undecorated pieces have vertical, fire-rounded rims, while decorated pieces have cracked-off rims. They were generally made of high quality colourless or green glass,, but yellowish green and dark green coloured beakers of poor quality were also found. The decoration mostly includes abrasion brands, sometimes combined with wheelcut lines. Blue chips were rarely used as decoration. The last type of conical beakers has a small, fattened, rounded

\footnotetext{
${ }^{28}$ DÉvAI 2012.

${ }^{29}$ BARKÓCZI 1988, Form 44-45 (Kat. 87-90); RÜTTI 1991, Taf. 70.1517-1520; CoOL-Price 1995, 69, Fig. 5.3.335; VessberG 1952, Taf. III. 40

${ }^{30}$ BARKóCZI 1988, Form 43; ŠArANOVIĆ-SveTEK 1986 , Tab. III; IsIngS 1957, Form 109c; GoetherT-PolascheK 1977, Form 58.

${ }^{31}$ RÜtti 1991, Form 64; Goethert-Polaschek 1977, Form 52; IsINGS 1957, 106.

32 BARKÓCZI 1988, Form 42; RÜTTI 1991, Form 63; GoETHERT-PolascheK 1977, Form 43.

${ }^{33}$ RÜTTI 1991, Form 60.1; Goethert-PolascheK 1977, Form 41; IsIngs 1957, 96; CotTAM-PRICE 1995, Fig. 48.
}

\footnotetext{
${ }^{34}$ BARKóczi 1988, Form 35 a,b; PIRLING 1989, Taf. 132; Taf. 16.

35 BARKóczi 1988, Form 37 a,b; Pirling 1979, 117; PIRLING 1989, Taf. 132, Taf. 16; Vessberg 1952, Pl. III.39.

${ }^{36}$ KISS 1997-1998, 237.

${ }^{37}$ BARKÓCZI-SALAMON 1968.

${ }^{38}$ BARKÓCZI 1988, Form 47a; RÜTTI 1991, Form 72; GoetherT-PolAscheK 1977, Form 58; IsINGS 1957, 109.

${ }^{39}$ BARKócZI 1988, Form 47b,c,d; RÜTTI 1991, Form 68; Goethert-PolascheK 1977, Form 53a; IsINGS 1957, 106a, b; CoOLPRICE 1995, Fig. 5.16.
} 


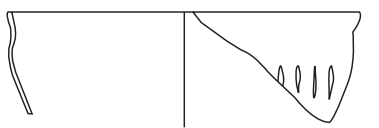

P5.2A

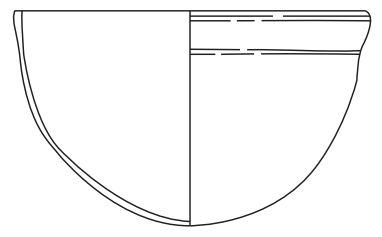

P5.2B

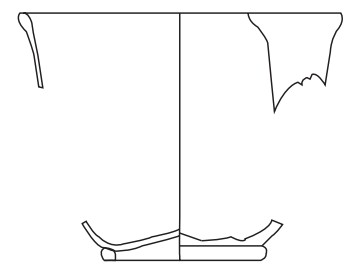

P6.1B

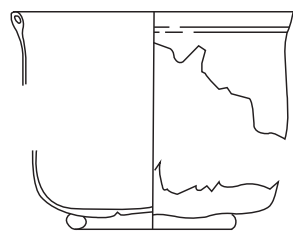

P6.2B

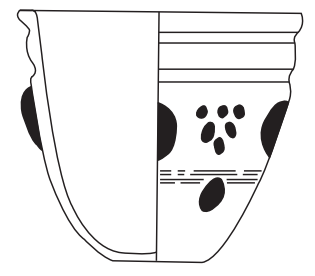

P7.2A

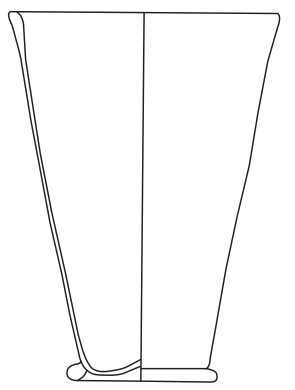

P8.1B

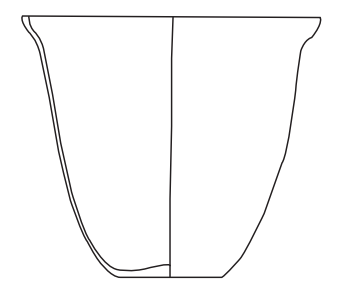

P7.1A

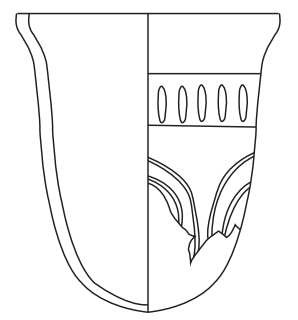

P7.2A

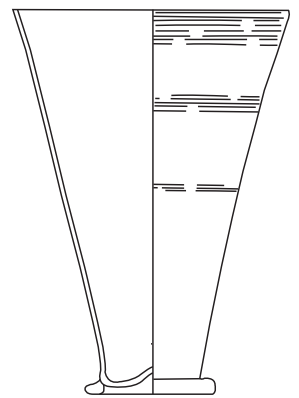

P8.2A

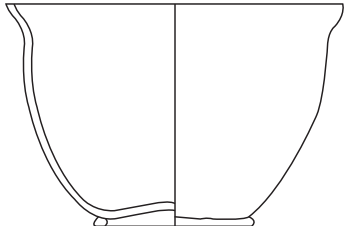

P6.1A

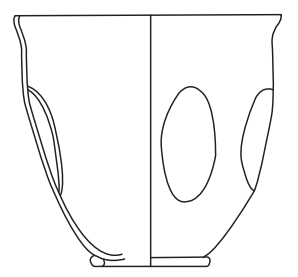

P6.2A

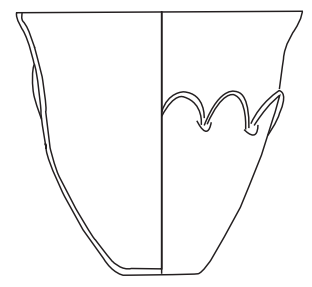

P7.2A

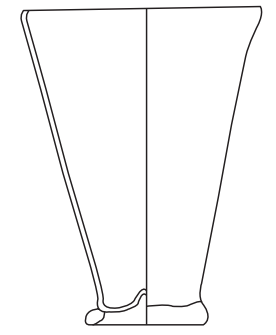

P8.1A

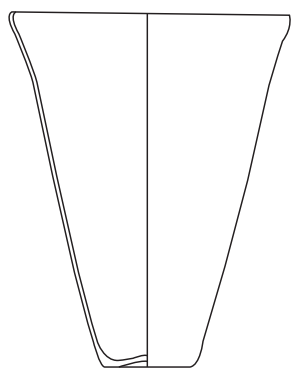

P9.1A

Fig. 2. Types of cups and beakers in late Roman Pannonia 


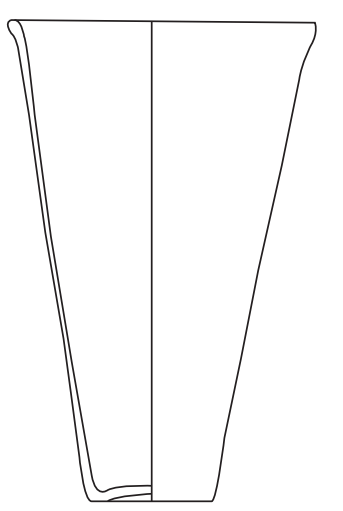

P9.1B

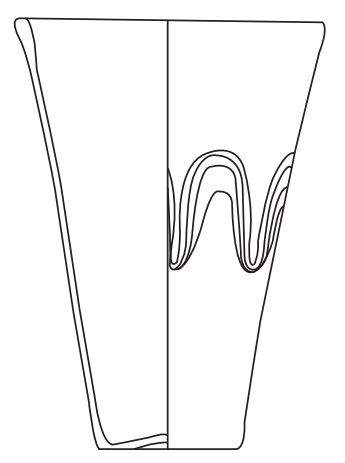

P9.2B

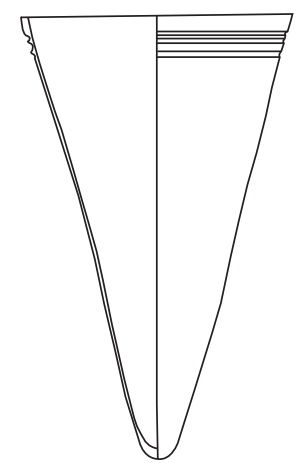

P10.2A

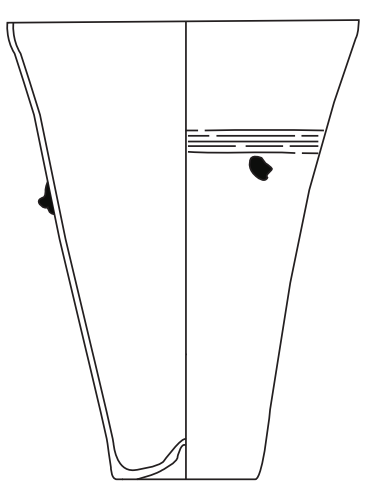

P9.2A

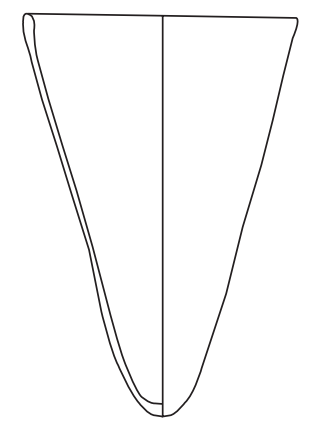

P10.1B
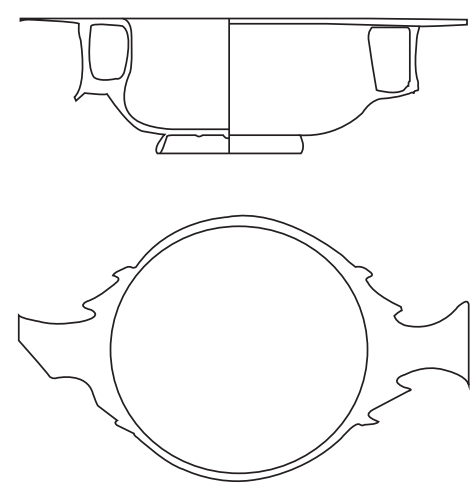

P11.2A

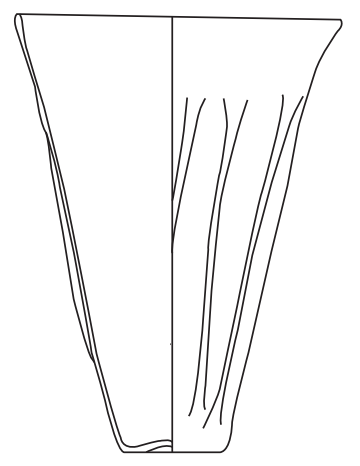

P9.2A

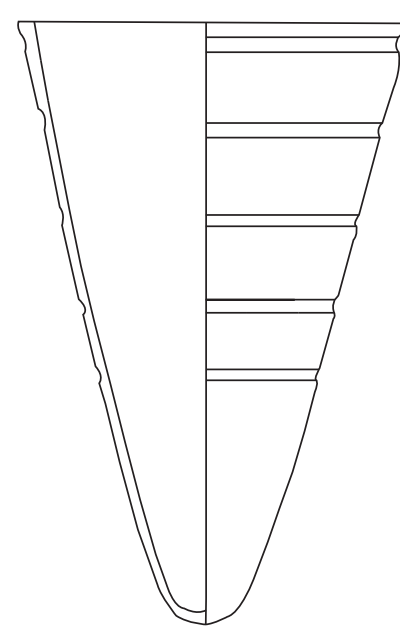

P10.2A

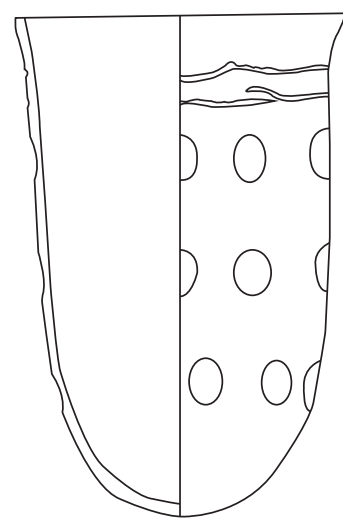

P12.2A

Fig. 3. Types of cups and beakers in late Roman Pannonia 
base (P 10)..$^{40}$ This type did not appear in many places (cemeteries) in Pannonia, and there are only nine examples of them. In all cases, they were made of good quality, colourless or naturally green materials. The rims are crackedoff, but polished. With the exception of a special piece from Mosdós, which was decorated with facet-cut cells, ${ }^{41}$ they were decorated either with thick, wheel-cut lines, or with abrasion brands. The fact that they were different from other conical beakers in size, quality and decoration, suggests that the former may have been used as a lamp. Only a few examples of both scyphons (P 11) (Fig. 3) ${ }^{42}$ and the Kowalk type beakers (P 12) (Fig. 3) $)^{43}$ are known from the late Roman period, which suggests they might not have been produced locally.

\section{Jugs}

The most common type is the globular jug (K 1) (Fig. 4) ${ }^{44}$ which was typical in urban settlements. The majority of the objects classified into this type were decorated either with single horizontal trails under the rim, or by optic-blowing. The indented globular jug found in Savaria, with its decorated base ring, is quite special. This type of jug existed from the first third of the 4th century AD in Pannonia, and was widely used in the second half of the century. Strong yellowish green versions of it still occur during the first half of the 5th century AD. Cylindrical jugs (K 2) (Fig. 4$)^{45}$ were typical along the limes between Mórichida and Intercisa, and also in Pécs and Ságvár. Their decoration involves single horizontal trails under the rim, and thin spiral trails on the neck. The jug found in Ságvár stands out for its single horizontal trail under the rim, and also for its handles, which were made of translucent, dark blue glass. Three-quarters of the pear shaped jugs (K 3) (Fig. 4$)^{46}$ are decorated. Three of them are unique. The translucent dark blue jug from Mosdós is remarkable: it was made by optic-blowing and its decoration is a spiral trail on the neck. the the body of one of the jugs found in Brigetio is decorated with diagonal ribs, and finally the decoration of a jug from Pécs consists of abrasion bands and facet-cut ovals. This type was common in the $4^{\text {th }}$ century $\mathrm{AD}$, but was not popular in the 5 th century AD.

\section{Storage vessels}

Storage vessels for liquids can be grouped into eleven different types (Fig. 4-6, Fig. 17). The majority of them were classified as the first group of globular bottles ( $\mathrm{Pa} \mathrm{1)} \mathrm{(Fig.} \mathrm{4).}{ }^{47}$ Three-quarters of them were undecorated, while others were typically decorated by optic-blowing or abrasion brands. This type was widespread from the end of the 3rd until the first half of the 5th century AD, whereas the type of globular bottles with funnel mouths (Pa 2) (Fig. 4) was less common, typically dating from the end of the 3rd to the first third of the 4th century AD. ${ }^{48}$ One example with an unfinished rim consisting of cylindrical molies was classified as a separate type by L. Barkóczi, but fits into this category. The Pa 3 (Fig. 5) group of bottles consists of only one piece, found in Majs, which had a pulled-in funnel neck. ${ }^{49}$ Objects of the final group of the globular bottles (Pa 4) (Fig. 5$)^{50}$ have base rings and quite often two loop handles. Only a few of them are known, dating from the first half of the 4th century AD. One is from Páty, and is decorated with double abrasion brands on its neck and doubled wheel-cut circles on its body. The next type is the cylindrical bottle with rounded shoulder ( $\mathrm{Pa} 5$ ) (Fig. 5), which was in use in the sec-

${ }^{40}$ BARKóCZI 1988, Form 47e; RÜTTI 1991, Form 69; GoEthert-PolascheK 1977, Form 54; Isings 1957, 106d; HARDEN1936, Plate XVI. 436-449.

${ }^{41}$ BARKóCZI 1988, Kat. 167.

${ }^{42}$ BARKÓCZI 1988, Form 187b; RÜTTI 1991, Form 97; GOETHERT-POLASCHEK 1977, Form 29a; IsINGS 1957, Form 39

${ }^{43}$ BarkócZi 1988, Form 75; Straume 1987, Form I-II; STERN 2001, 333.

${ }^{44}$ BARKÓcZI 1988, Form 155,159, 160, 169; RÜTTI 1991, Form 169; GoEthert-PolascheK 1977, Form 117; CotTAM-Price 1998, Fig. 69, 73, LaZAR 2003, Form 5.1.3 and 5.1.8, 5.1.9.
${ }^{45}$ BARKÓCZI 1988, Form 154 and 168 b,c,d,e; RÜTTI 1991, Form 171; GoETHERT-POLASCHEK 1977, Form 125; IsINGS 1957, Form 126.

${ }^{46}$ BARKÓCZI 1988, Form 158 and 170, 173, 175, 176; RÜTTI 1991, Form 172; GoETHERT-POLASCHEK 1977, Form 124; IsINGS 1957, Form 120; CotTaM-Price 1998, Fig. 72; LaZAR 5.1.2.

${ }^{47}$ BARKÓCZI 1988, Form 118, 119 and 123; RÜTTI 1991, Form 154; Goethert-PolascheK 1977, Form 93; Isings 1957, Form 103; LAZAR 2003, Form 6.2.1-3 and 6.2.6-7.

${ }^{48}$ BARKÓCZI 1988, Form 121; IsINGS 1957, Form 104; LAZAR 2003, Form 6.2.8

${ }^{49}$ BARKÓCZI 1988, Kat. 305; LAZAR 2003, Form 6.2.4.

${ }^{50}$ HARTER 1999, Form G27c. 


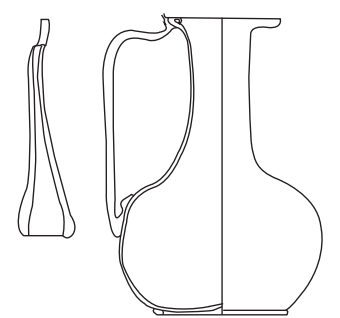

$\mathrm{K} 1.1 \mathrm{~B}$

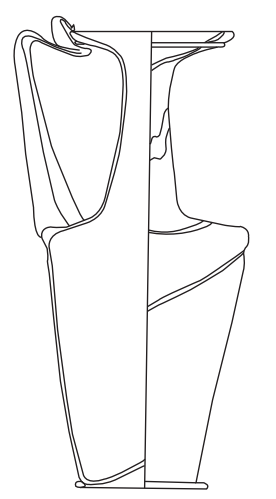

$\mathrm{K} 2.2 \mathrm{~A}$

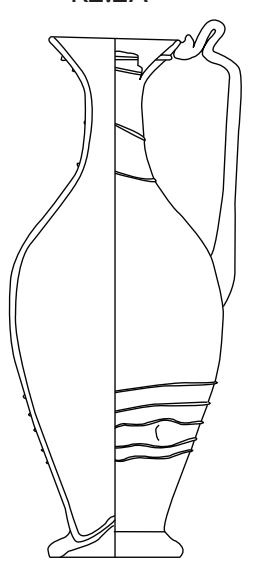

$\mathrm{K} 3.2 \mathrm{~B}$

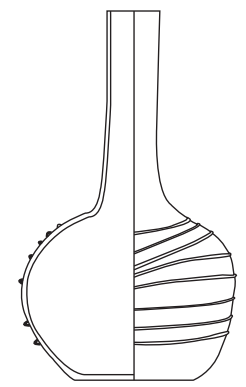

Pa1.2A

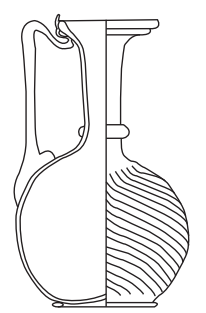

$\mathrm{K} 1.2 \mathrm{~B}$

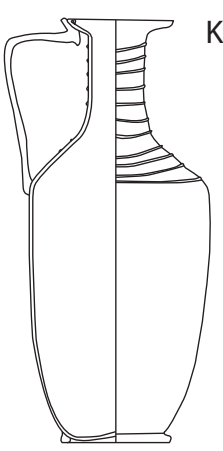

$\mathrm{K} 2.2 \mathrm{~A}$

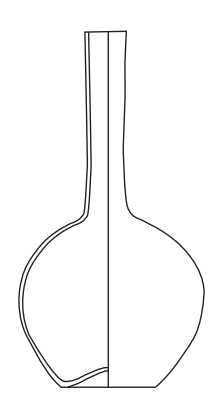

Pa1.1A
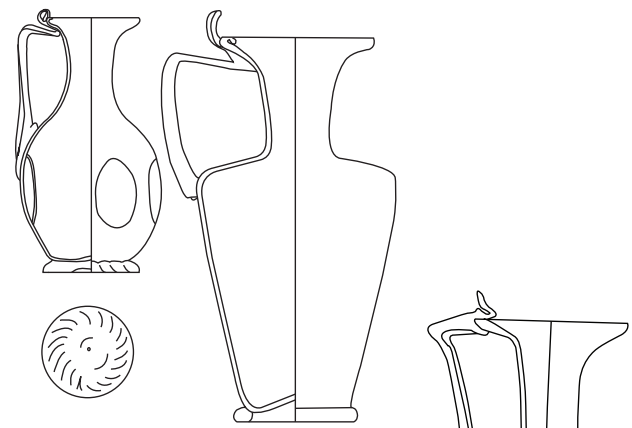

$\mathrm{K} 1.2 \mathrm{~B}$

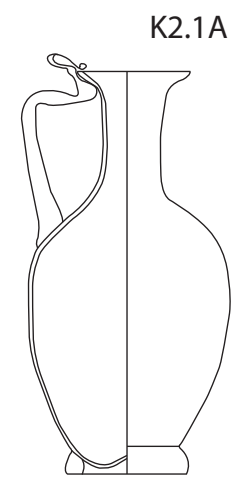

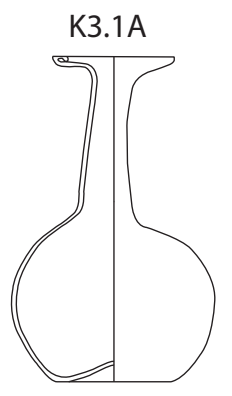

Pa1.1B

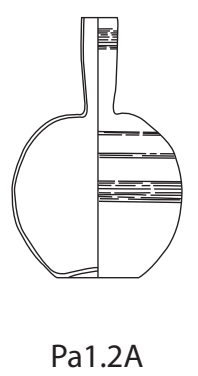

Pa1.2A

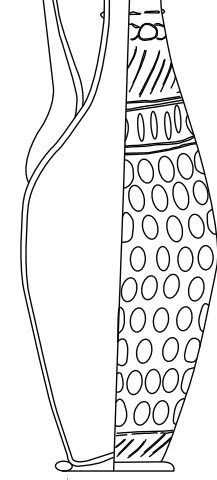

$\mathrm{K} 3.2 \mathrm{~A}$

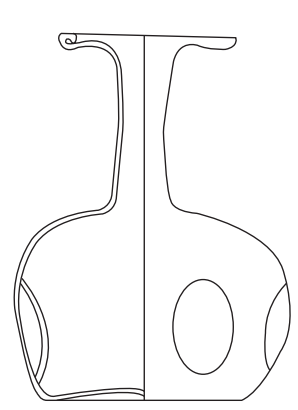

Pa1.2B

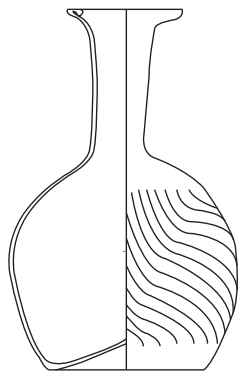

Pa1.2B

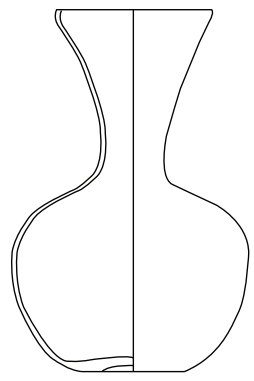

Pa2.1A

Fig. 4. Types of jugs and bottles in late Roman Pannonia 
ond half of the 4th and the beginning of the 5th century AD. ${ }^{51}$ They were usually made of poor quality, strong yellowish green coloured materials, and almost half of them were decorated by optic-blowing. They occur particularly at sites along the Danube Bend, between Arrabona and Intercisa. Square bottles (Pa 6) (Fig. 5) (52 $^{52}$ were rare in Late Roman Pannonia. Their bases usually do not have a pattern, but pontil marks can be identified on them, indicating that they were blown freehand, while their bodies were mould-blown. The hexagonal undecorated bottles (Pa 7) $(\text { Fig. } 5)^{53}$ were not common either; only three pieces are known. One type of decagonal bottle (Pa 8) (Fig. $5)^{54}$ was the only example amongst the finds. The last group consists large cylindrical bottles with horizontal shoulders ( $\mathrm{Pa}$ 9) (Figs 5-6). ${ }^{55}$ These were made from strong yellowish green glass materials, full of tiny, dark specks. Abrasion lines usually divided the surface of the bottles into three or five fields decorated with facet-cut ovals. They date to the second half of the $4^{\text {th }}$ and the first half of the $5^{\text {th }}$ centuries AD. There is an amphora with handles, made of strong yellowish green glass, with a base knob (Pa 10) (Fig. 6). It is embellished with a single blue, opaque horizontal trail under the rim. ${ }^{56}$ Its body is divided into three spheres decorated with abrasion lines and cell shaped facet-cut patterns. It dates to the last third of the 4 th or to the first half of the $5^{\text {th }}$ century AD. There is also a globular amphora with a base ring (Pa 11) (Fig. 6) made by optic-blowing. It has an opaque, dark blue base and handles ${ }^{57}$ and dates to the first half of the $4^{\text {th }}$ century AD. The only known jar (F 1) (Fig. 6) was found in a sarcophagus in Szekszárd. ${ }^{58}$

\section{Unguentariae}

The group of unguentaria appears to be the most diverse, but most types are represented by single pieces (Figs 6-7, Fig. 18). The most common type was the globular one (I 1) (Fig. 6). ${ }^{59}$ These vessels had mostly asymmetric bodies, and their necks often leaned in one direction. They were made of lower-quality glass than other, free blown vessels from earlier periods. This type of vessel can be found until the end of the 4th century AD. Globular unguentaria with a funnel mouth and rolled-in rim (I 2) (Fig. 6) were less frequent, ${ }^{60}$ and typical only in the 4th century AD. A small, indented globular unguentarium with a wide, cylindrical neck found at Ságvár (I 3) (Fig. 6) ${ }^{61}$ is the only representative piece dating from the 4th century AD. Drop-shaped vessels (I 4) (Fig. 6) and conical bottles (I 5) (Fig. 6) were also rare in the $4^{\text {th }}$ century, only three representative pieces were found of the former. ${ }^{62}$ Types I 6-11 I (Fig. 6) include indented unguent bottles, each form represented by only one find. The differences between the types range from the shape of the body, the length and form of the necks, and the shape of rims to the number of indentations. ${ }^{63}$ Type I 12 (Fig. 7) is represented by a small bottle with a cylindrical body and neck, and a funnel rim. It was found in Esztergom-Bánom, and to date no similar pieces are known. Type I 13 (Fig. 7) similarly consists of a single piece. The very small, jar shaped unguentarium with a double curved rim, was found in Pécs and has no known equivalent so far. Type I 14 (Fig. 7) is an indented, hexagonal unguentarium. This unique piece was found in Brigetio has no known parallels. Small, conical unguentaria with funnel rims were categorized as Type I 15 (Fig. 7), and rod shaped, long, narrow ones without necks as Type I 16 (Fig. 7). ${ }^{64}$ Type I 17 (Fig. 7) is once again represented only by one item: a fattened, globular unguentarium dating from the $4^{\text {th }}$ century AD. The most common

\footnotetext{
${ }^{51}$ HARTER 1999, Form F3b.

${ }^{52}$ BARKÓCZI 1988, Form 167c; RÜTTI 1991, Form 156; GOETHERT-POLASCHEK 1977, Form 114/119; ISINGS 1957, Form 50; LaZAR 2003, Form 6.3.2; CotTAM-Price 1998 Fig. 89.

${ }^{53}$ BARKÓCZI 1988, Form 167 f; RÜTTI 1991, Form 158; Goethert-PolascheK 1977, Form 113; Lazar 2003, Form 6.3.3; CotTAM-Price 1998 Fig. 90.

${ }^{54}$ BARKÓCZI 1988, Form 167g.

${ }^{55}$ BARKÓCZI 1988, 168c; RÜTTI 1991, Form 171; Goethert-PolascheK 1977, Form 125; IsINGS 1957, Form 126; LAZAR 2003, Form 6.3.6; CotTAM-Price 1998 Fig. 92-93.

${ }_{56}^{56}$ BARKÓCZI 1988, Form 184; STERN 1977, Form 4.A.1.b.

${ }^{57}$ STERN 1977, Form IB3a.

${ }^{58}$ RÜTTI 1991, Form 114; GoETHERT-POLASCHEK 1977, Form 147c; IsINGS 1957, Form 68; LAZAR 2003, Form 7.2.2.
}

${ }^{59}$ BARKÓCZI 1988, Form 90; RÜTTI 1991, Form 146; LAZAR 2003, Form 8.6.15. and 8.6.16.

${ }^{60}$ RÜTTI 1991, Form 148; LAZAR 2003, Form 8.6.14.

${ }^{61}$ RÜtTI 1991, Form 147.1; Goethert-PolascheK 1977, Form 77.

${ }^{62}$ RÜTTI 1991, Form 126; LAZAR 2003, Form 8.6.1.

${ }^{63}$ GREGL-LAZAR 2008, 91; DÉVAI 2012, form I 6-7 and I 11: no paralells; Form I 8: RUŽIĆ 1994, T. XXII.7; RÜTTI 1991 FoRM 147.2; Goethert-PolascheK 1977, Form 78; Form I 9: BARKóCZI 1988, Form 97; BARKÓCZI 1988, 123; GREGL-LAZAR 2008, 91., Pl. 21.2; Fadić 2006, 48., Br. Kat. 52; Avellier-Dulong-NenNa 2005, 405, Kat. Nr. 1107; Form I 10: RuŽÍ́ 1994, T. III/10b; RÜTTI 1991 Form 147.2; GoETHERT-PolascheK 1977, Form 78

${ }^{64}$ RÜTTI 1991, Form 138; HARTER 1999, Form D10. 

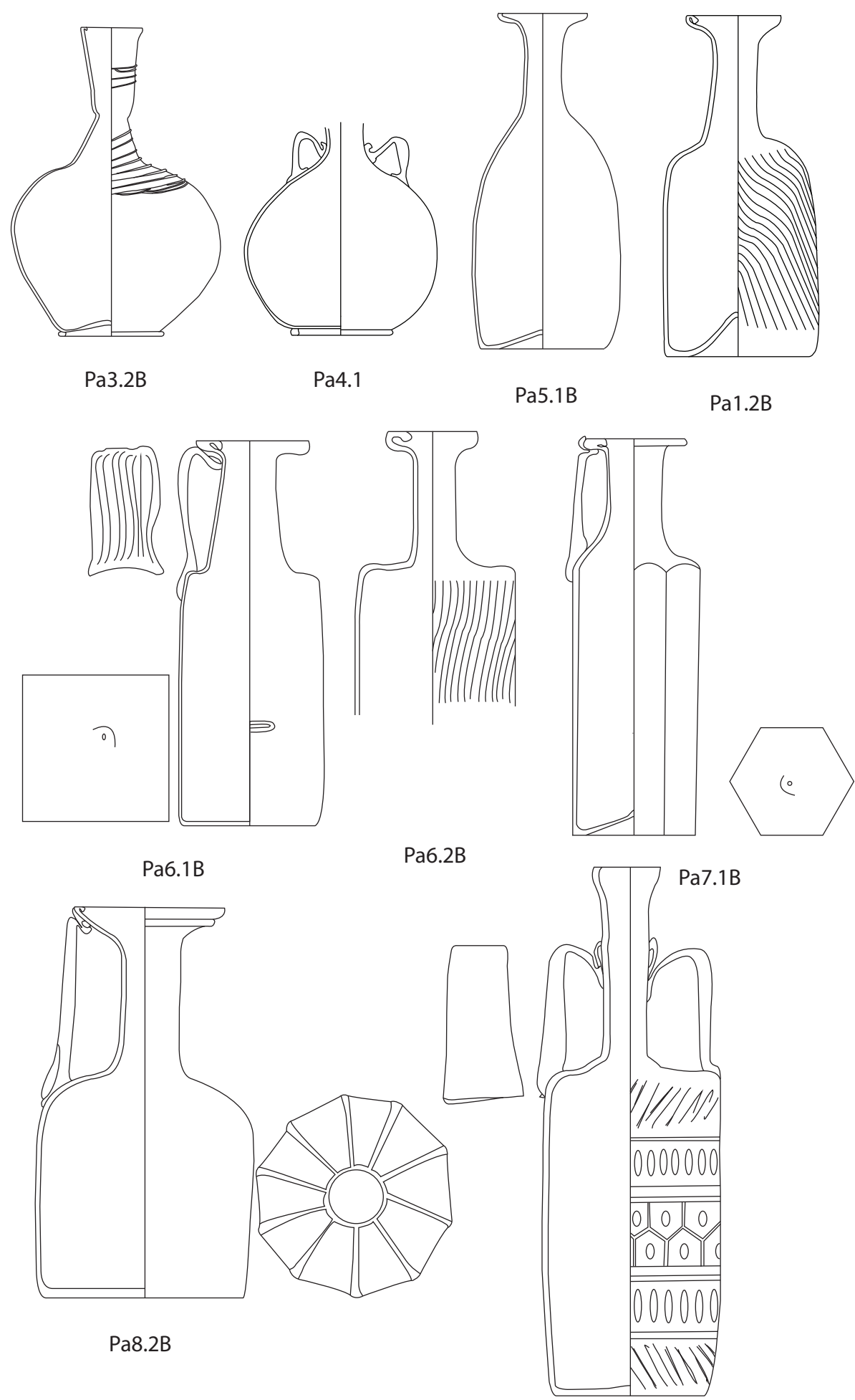

Pa9.2A

Fig. 5. Types of bottles in late Roman Pannonia 
type was I 18 (Fig. 7), ${ }^{65}$ which was a long, narrow, pipette shaped unguent bottle. More than 50 pieces were found in Pannonia, and there existed small and large variants. They were used from the second third of the $4^{\text {th }}$ century AD until the first half of the 5th century AD. Type I 19 includes an unguent ball without a neck or rim, ${ }^{66}$ of which only one example was found in Pécs. It dates from the $4^{\text {th }}$ century AD, which is exceptional. Aryballoi (I 20) (Fig. 7) are uncommon in the Late Roman period. ${ }^{67}$ There is only one known piece of this type from Ságvár, and it is decorated with single horizontal trails.

\section{Miscellaneous objects}

With regards to the category of Miscellaneous objects (E) (Fig. 7), type E 1 is represented by only one piece found in a man's grave in Bátaszék-Kövesd. It is a small, cylindrical vessel with a base knob and cracked-off rim, and the body is decorated with abrasion bands. ${ }^{68}$ It was probably used as a lamp. Type E 2 includes animal shaped vessels, which were uncommon in the Late Roman Period. ${ }^{69}$ E 3 represents a group of small $(12-15 \mathrm{~cm}$ high), elongated, conical vessels. The bodies of these vessels are similar to amphorae with base knobs, but they have funnel necks. Since they do not have handles and their necks are different from amphorae, they cannot be classified as such. One of them was found in Pécs, the other one is from the cemetery of Páty. ${ }^{70}$ Their exact parallels are not known; they might have functioned either as drinking vessels or unguentaria. The one from Pécs, is decorated with abrasion brands on its neck and body, as well as small, tubular handles attached to its shoulder. This suggests that the vessel, along with other representatives of this type, could be hung and used as a lanp, Category E 4 stands for dropping flasks. ${ }^{71}$ This type was common until the last third of the $4^{\text {th }}$ century AD. Later their presence became more sporadic. There are only three known pieces, these date to the end of the 4th century AD and the beginning of the $5^{\text {th }}$ century AD. Category E 5 is comprised of six small jar shaped vessels from the second half of the $4^{\text {th }}$ century AD. ${ }^{72}$ Vasa diatreta belong to the group E $6 .^{73}$

Identifying imported articles is a demanding task. It very likely in the late Roman Period most vessels were produced within the province and their raw material was supposedly provided by primary workshops. That said, raw materials might have originated from other primary workshops as a result of changes to commercial routes. New sources of raw materials may have been the reason behind the changes in the shade and colour of glass.

Another hypothesis is that different standards of workshops existed to meet local demand within the province. The importance of glass production in the late Roman Period in Pannonia is illustrated by the vast number of glass vessels, series of objects and some other particular types of objects. Therefore, unique vessels that stand out can be identified as imported ones because they diverge in their forms, decorations, colours and qualities from the ones dominating the area at different points in time.

Remarkable variability characterises the finds from the different regions in the province from the end of the second half of the $4^{\text {th }}$ century AD. Simple, undecorated vessels for everyday use such as cups, flasks, unguentariae were typically found along the limes and in the area of the Danube Bend, whereas a diversity of forms, decorations and quality characterised the objects found inside the province the urban settlements, especially in South of Valeria (Fig. 8). Some unique pieces, not likely to be local products, were found in Sopianae and its surrounding area, as well as in the cemetery of Ságvár. ${ }^{74}$ Other, supposedly imported vessels were found in Aquincum and date to the middle of the $4^{\text {th }}$ century AD. From the end of the $3^{\text {rd }}$ century to the middle of the $4^{\text {th }}$ century, glass items were produced in series and shared identical features. These series can be considered local products and include shallow convex bowls, round plates (T 1,2,4,5), slim beakers with curved body, slim cylindrical beakers, hemispherical cups

\footnotetext{
${ }^{65}$ BARKÓCZI 1988, Form 103; IsINGS 1957, Form 105; Goethert-Polaschek 1977, Form 85; Harter 1999, Form D18b; CoOL - Price 1995, Fig. 86.

${ }^{66}$ RÜTTI 1991, Form 124; IsIngs 1957, Form 10.

${ }^{67}$ RÜTTI 1991, Form 151; IsINGS 1957, Form 61; GOETHERT-POLASCHEK 1977, Form 135.

${ }^{68}$ Crowfoot-Harden 1931, 202; Lazar 2003, 200; RuŽIĆ 1994, 56, Kat. 1189; Jennings 2004-2005, 146, Fig. 6.20.9; SAGADIN 2004, 113, Fig. 6.1.
}

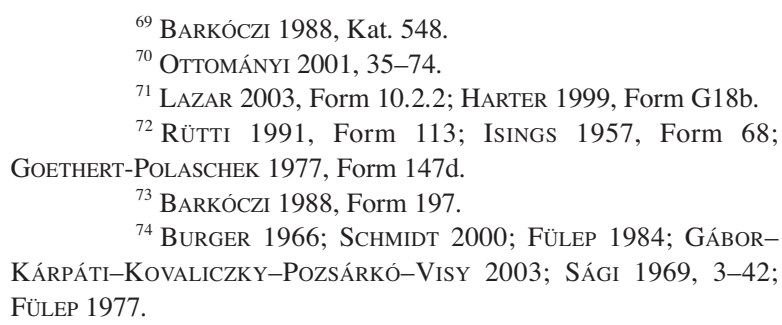




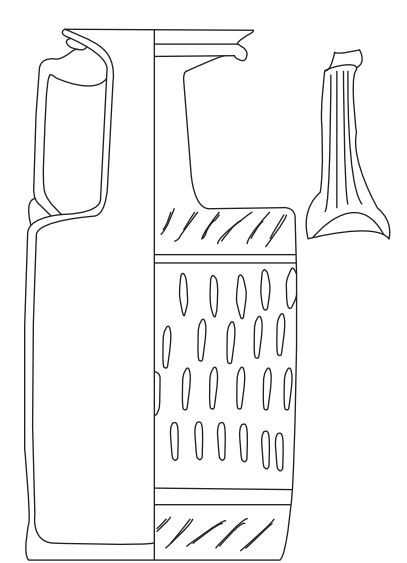

Pa9.2B

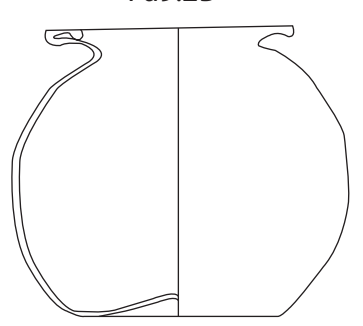

F1.1B
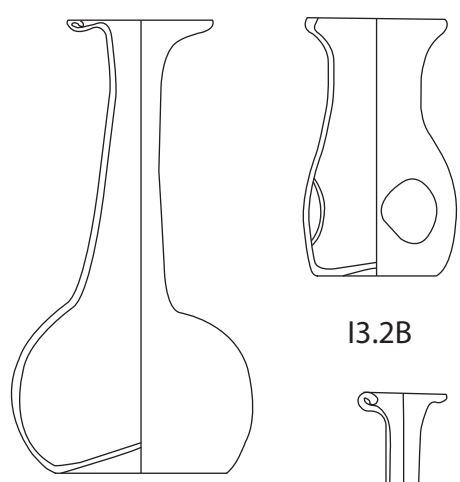

13.2B

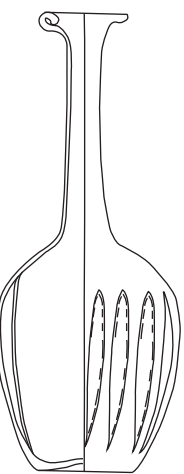

18.2B

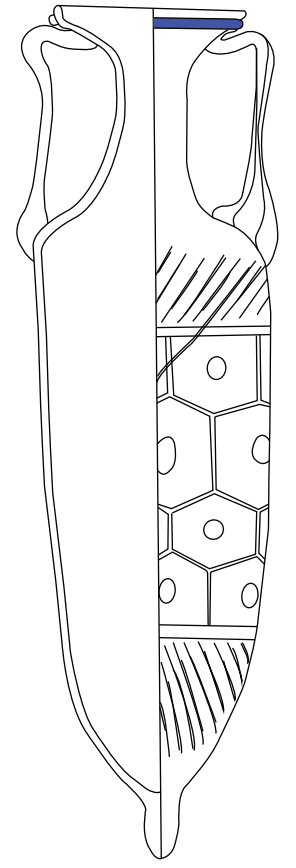

Pa10.2B

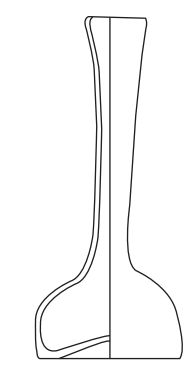

I1.1A

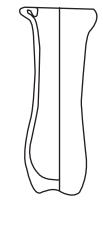

14.1B

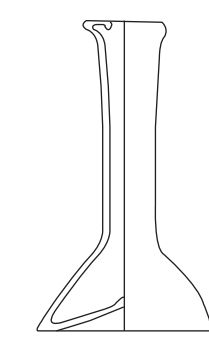

I 5.1B

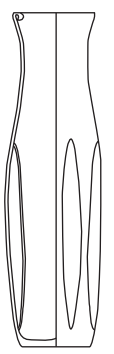

19.2B
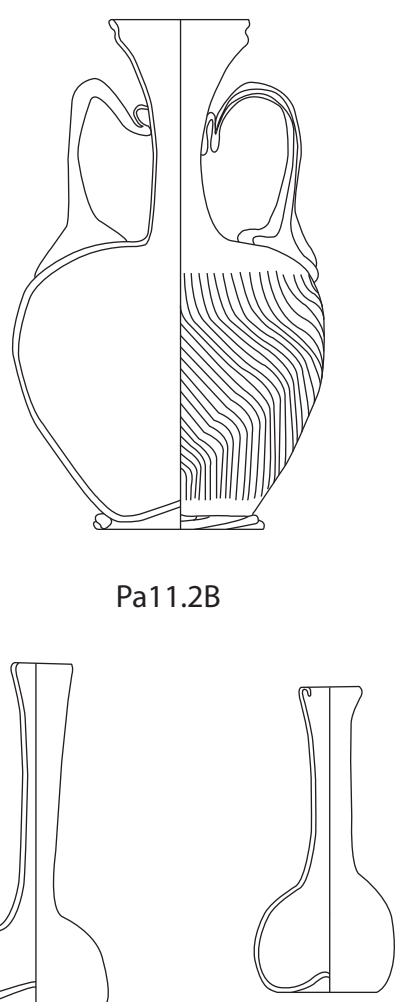

I 1.1B

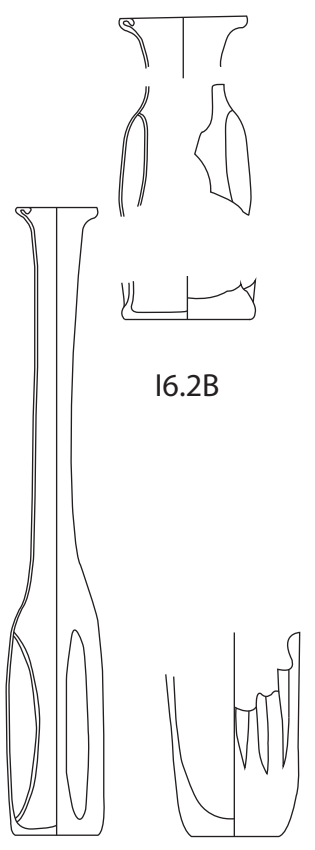

I 10.2B

111.2

Fig. 6. Types of bottles, amphorae, jars and unguentariae in late Roman Pannonia 


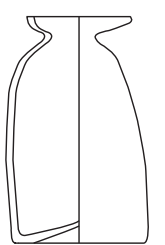

I12.1B
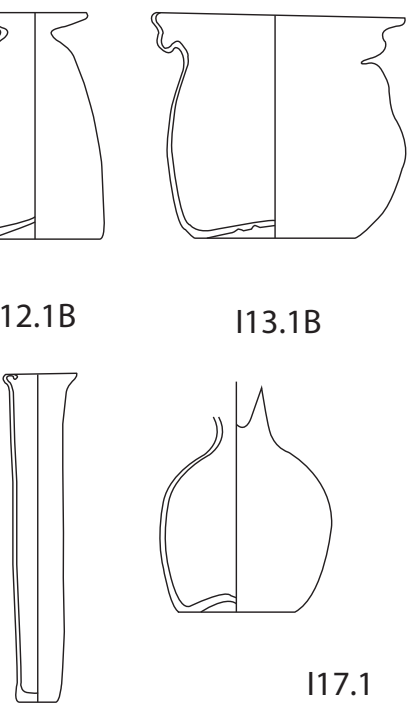

I13.1B

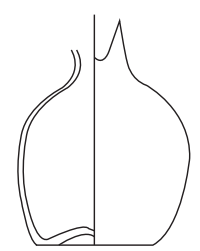

117.1

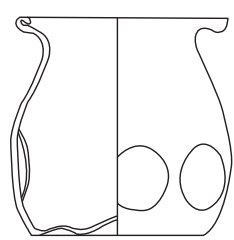

I14.2B

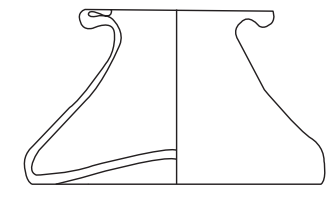

I15.1B
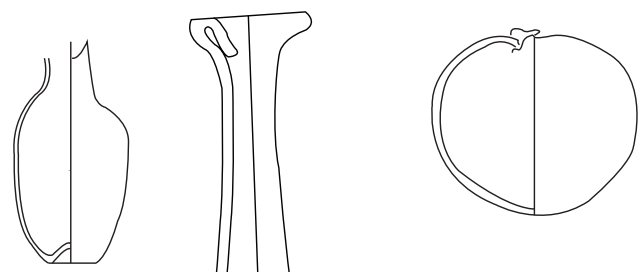

I19.1A

I16.1B

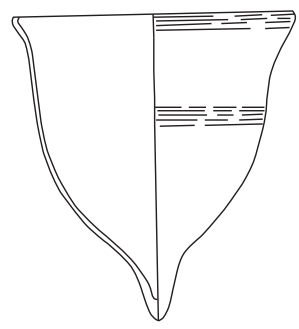

E1.2A

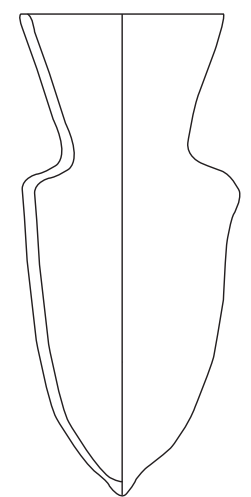

E3.1B

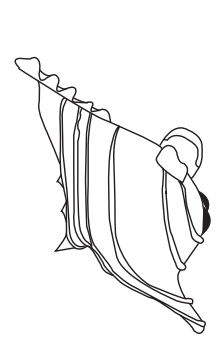

E2.2

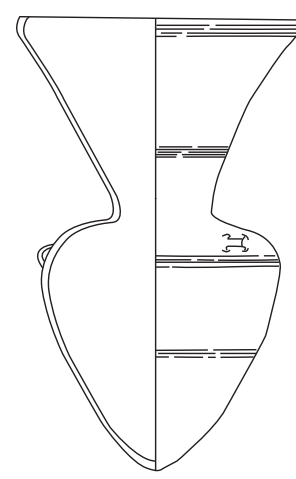

E3.2A

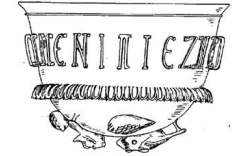

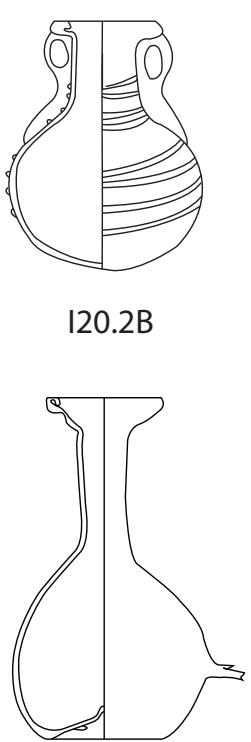

E4.1B

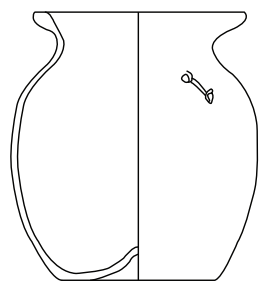

E5.1B

E6.2A

Fig. 7. Types of unguentariae and miscellaneous objects in late Roman Pannonia (E6.2A is drawn after BARKócZY 1988, 219, Kat. Nr. 985) 


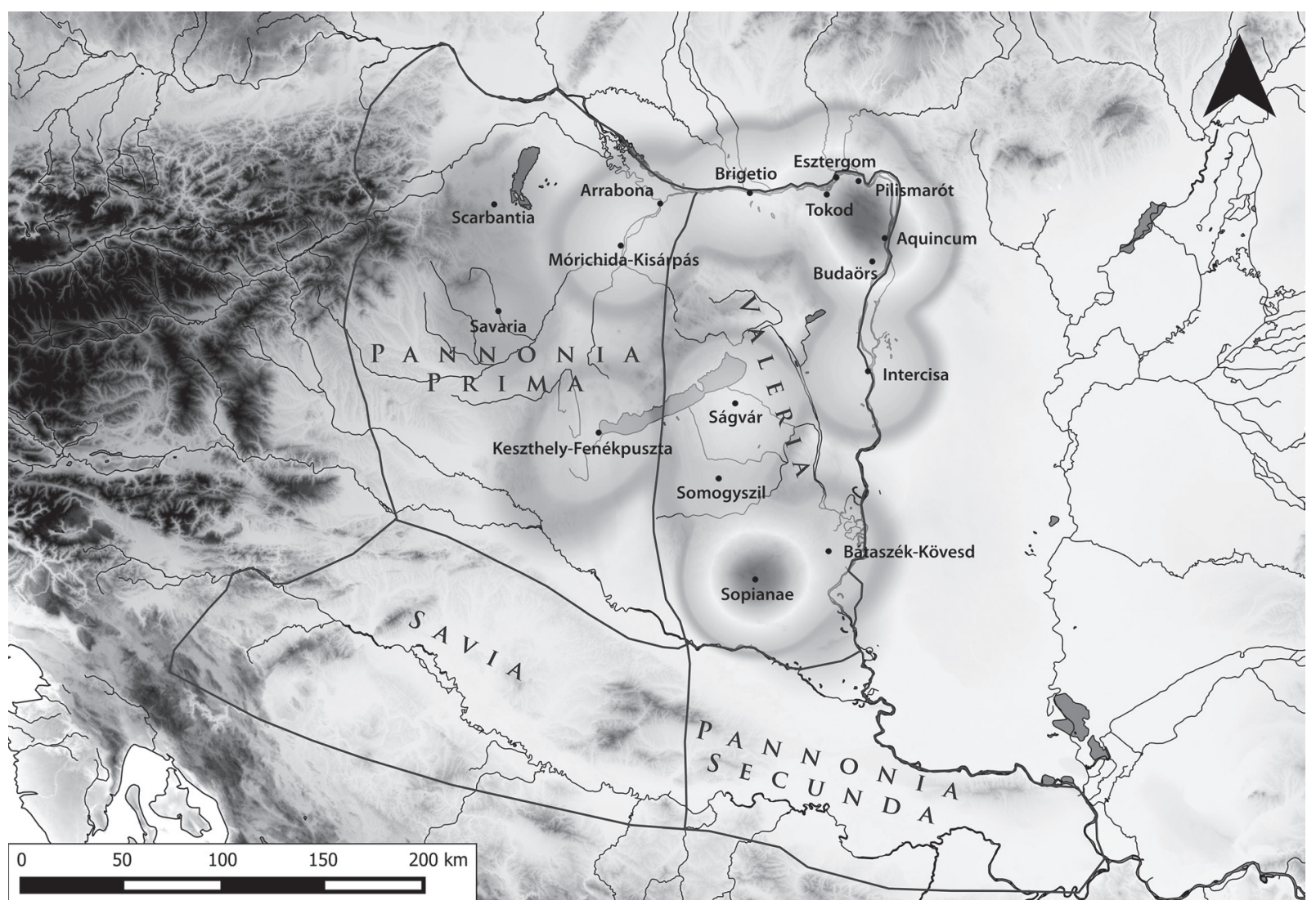

Fig. 8. Distribution of late Roman glass vessels in Pannonia (made by L. Rupnik)

(P1-P5), either globular or cylindrical or pear-shaped jugs (K1, 2, 3), either globular or cylindrical or square or hexagonal or decagonal bottles (Pa 1,2,3,4,5,6,7,8), either globular or drop-shaped or conical unguentariae, indented unguent bottles, and either cylindrical or hexagonal or rod-shaped or flattened globular or pipette-shaped unguentarie. $^{75}$

Most of theforms dating from the second half of the $4^{\text {th }}$ century AD to the first half of the $5^{\text {th }}$ century AD were represented by provincial articles. During this time, the predominance of convex and shell-shaped bowls blown in an open mould is remarkable. The pattern of the scalloped shell featuring cutting edge rims was not considered sophisticated in the $4^{\text {th }}$ century AD. Their style is in contrast to earlier products of Italian origin from the $1^{\text {st }}$ century AD decorated with realistic illustrations. These scallop shell-shaped bowls were common in the in areas near Cologne and in Pannonia. Therefore they are assumed to have been produced in these regions. ${ }^{76}$ Apart from this late Roman form being favoured in Intercisa, some examples are also known from the Danube Bend and from Aquincum. ${ }^{77}$

The second half of the 4th century AD and the first half of the 5th century AD are characterized by what are assumed to be locally produced cups, including both hemispherical or convex ones with curved rims (half egg shaped), and conical ones. Amongst the conical vessels the ones with a base ring, and ones with a flat base were popular. In contrast, vessels with a rounded base were rare, represented by only nine pieces, some of which were imported items. The conical cup form frequently occurs in late Roman burials in Pannonia. We know of more than 300 specimens from different cemeteries, most of which have either flattened bases or base rings created by applying one circular trail of glass. ${ }^{78}$ Evidence of cups with flattened bases being used can be found on a fresco from the II. tomb in Pécs and a fresco from Ostia. ${ }^{79}$ The inscription, ПEIE ZHCHC EYTYX $\Omega$ C was engraved on a beaker

\footnotetext{
${ }^{75}$ DÉvai 2012.

${ }^{76}$ STERN 1995, 185-199.

${ }^{77}$ BARKÓCZI 1988, 212; KELEMEN 2008, grave 262; VÁGÓ-
}

${ }^{78}$ DÉvaI 2012, 159-166.

${ }^{79}$ FÜLEP 1984, 42, Pl. XX; STERN 2001, 265-266. BóNA 1976, grave 38, 494, 570 . 


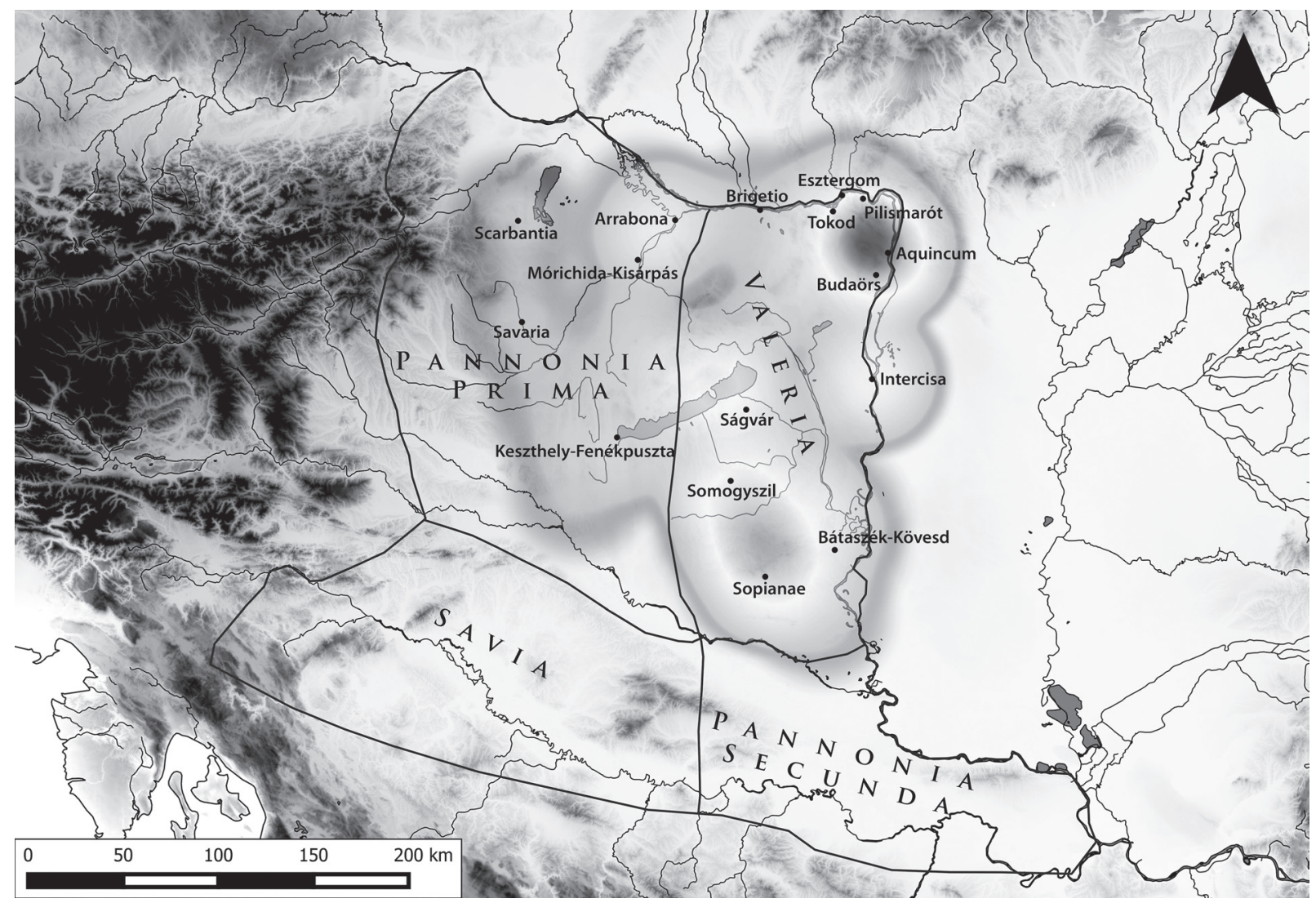

Fig. 9. Distribution of bowls (made by L. Rupnik)

found in a grave Nr. 212, located in the Ságvár cemetery which demonstrates that the vessel was used for drinking. ${ }^{80}$ The rounded base variant is seen only rarely (Only ten examples in Hungary have been found so far: three from Ságvár, three from Bátaszék-Kövesd, one from Mosdós, one from Pilismarót, one from Balatonfüred, and one with an unknown find place).$^{81}$ It is unlike that for many of the previously mentioned finds, the raw materials used to craft rounded base variants would always have been ofhigh quality. In addition, they are usually decorated with horizontal wheel-cut lines or horizontal abraded bands, and one of them has cell-shaped facet cuts. In most cases the rims on these finds are cracked off and polished. Two examples of fire rounded rims were found in graves Nr.143, and Nr. 152 in Bátaszék-Kövesd. ${ }^{82}$ Cups with a conical form that have a base knob or a rounded base tend to be either bigger or smaller than ordinary cups. The volumetric capacity of the average cup is about 2-3 dl. The cupform in grave Nr. 262 in Ságvár, which held two children, has a volume exceeding $8 \mathrm{dl}^{83}$ The majority of cupforms with rounded bases, as well as ones with a base knob, are mostly found in South-Valeria (Ságvár, Bátaszék-Kövesd and Mosdós). For these reasons, beaker forms with rounded bases or base knobs (E 1) ${ }^{84}$ were likely used as lamps.

The well-known cup with a Greek inscription from $\operatorname{Ság}{ }^{85}(\mathrm{P} 9)$ was made of good quality materials and was embellished with a varied decoration system, which incorporated small blue blobs in one line. These blobs did not occur frequently on flat-based conical beakers in Pannonia. The inscription cut underneath the rim includes several thin lines, as well as a wavy line between which abraded oval spots can be observed. Although the decoration is complex, the execution is not sophisticated. Another find, also containing a Greek inscription and blue blobs,

${ }^{80}$ BARKÓCZI 1988, 102; BuRGER 1966, 121; KovÁCs 2007, 45.

a cutting enge rim. its body is decorated with abrasion bands. It was

${ }^{81}$ DÉvAI 2012, 166-168.

${ }^{82}$ PÉTERFI 1993, 76-77.

${ }^{83}$ DÉVAI 2012b, 264. probably used as a lamp. The form from a man's grave Nr. 21 in Bátaszék-Kövesd has a capacity of $1.2 \mathrm{dl}$.

${ }^{84}$ A lamp form with base knob was in grave $\mathrm{Nr} .21$ in

${ }^{85}$ BARKÓCZI 1988, 102; Burger 1966, 121; KovÁCs 2007, 45. Bátaszék-Kövesd. It is a small, cylindrical vessel with a base knob and 


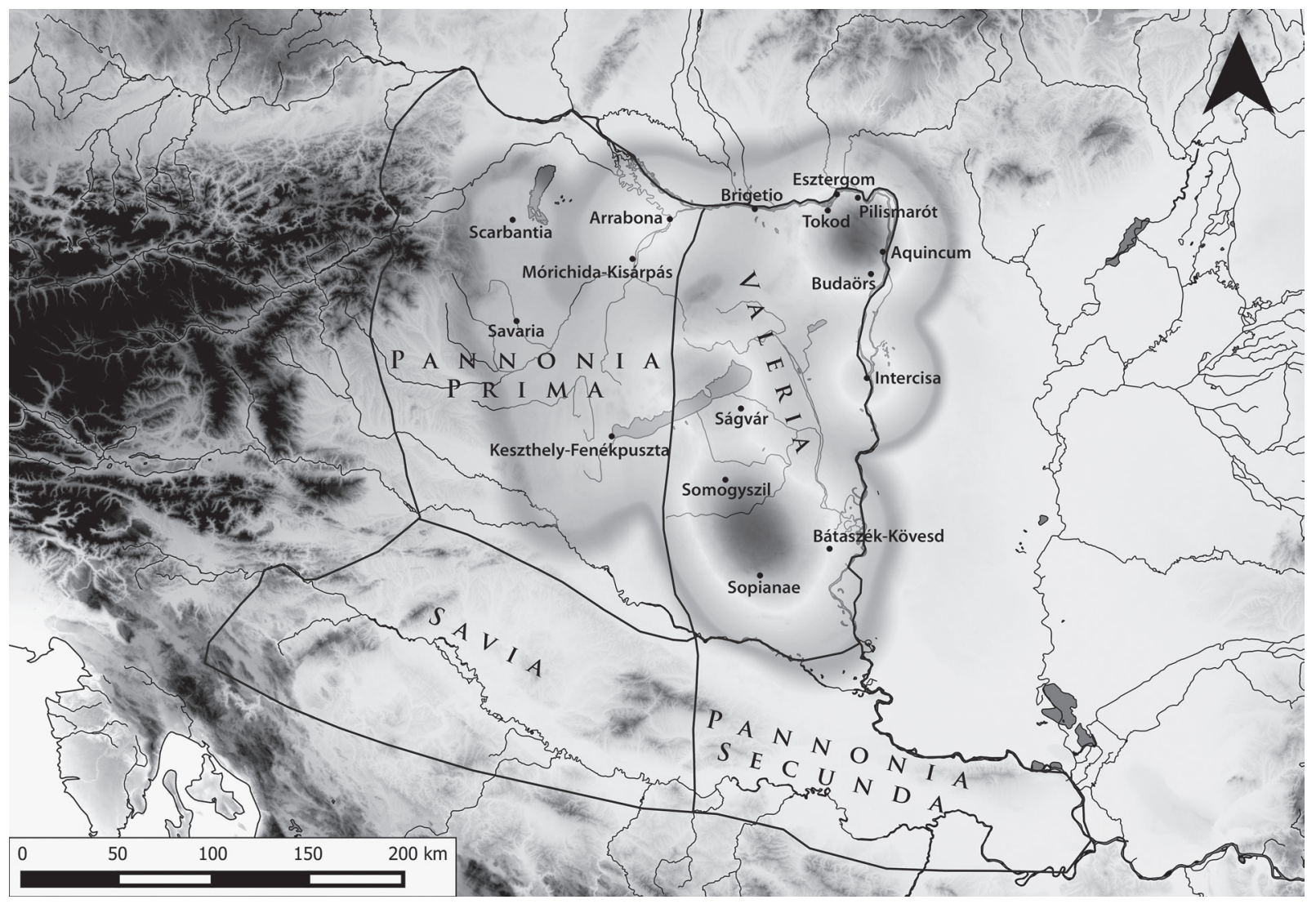

Fig. 10. Distribution of shell shaped bowls (made by L. Rupnik)

was discovered in the territory of Pannonia Secunda. ${ }^{86}$ Much like the high quality, rounded-base conical cups (P 10) which have refined wheel-cutting bands or cell-shaped facet-cutting, the above mentioned vessels are unlikely to have been manufactured locally. One important representative of this type of vessel is from Ságvár. ${ }^{87}$ It features a wheel-cut band and has is similar to its counterpart from Salona. ${ }^{88}$ A different cell-shaped cup from Mosdós is parallel to another item found in, the Sassanida area that dates to the $5^{\text {th }}$ or $6^{\text {th }}$ century $\mathrm{AD}$, and is exhibited in the Corning Museum. ${ }^{89}$

The scyphos form (P 11) ${ }^{90}$ of which two versions existed in the Province, is rare in the late Roman Period. One version is tall, blown and simply executed, while the other is small, mainly cast and carefully elaborated. ${ }^{91}$ This variant form is represented by two pieces from Aquincum. One of them is a small, cast specimen polished both on the inside and the outside. It has a cutting edged smooth rim and two plain, horizontal rectangular handles. The other piece is a wide-mouthed short cup with a missing handle, that can be defined as a scyphos. It is decorated with a carved, plastically emerging inscription reading PALM CHI, and by three cut horizontal bands with a wheat spike near the lower part. ${ }^{92}$ These two scyphos vessels are unlikely to have been local products based on their elaborations, decorations and quality. Their counterparts can be found in Zülpich-Eisen, a fact supports the idea that they were produced in the Rhineland in the second half of the $4^{\text {th }}$ century $\mathrm{AD} .^{93}$ The $\mathrm{P} 12$ cups, represented by only two pieces, which originate from Sopianae, belong to the Kowalk type,${ }^{94}$ were rarely found within the Province. L. Barkóczi

86 ŠARANOVIĆ-SVETEK 1986, Tab. IV.1; KOVÁCS 2007, 53 : Accipe calice (m), pie, zes(es).

${ }^{87}$ Burger 1966, 126, Fig. 115, grave 262.

${ }^{88}$ FADIĆ 1997, 202.

${ }^{89}$ PerRot 1967, 135

${ }^{90}$ ISINGS 1957, Form 39; RÜTTI 1991, Form 97; GOETHERTPOLASCHEK 1977, Form 29a.
${ }^{91}$ ZSIDI 2005, 59-61; TOPÁL 1993, 51, Grave 122.

92 Topál 1993, 51, Grave 122.

${ }^{93}$ FollmanN-Schulz 1992, 70-71, KAT. NR. 39. Inscription: ZHCAIC KA $\Lambda$ WC.

${ }^{94}$ Straume 1987, Typ I-II. 


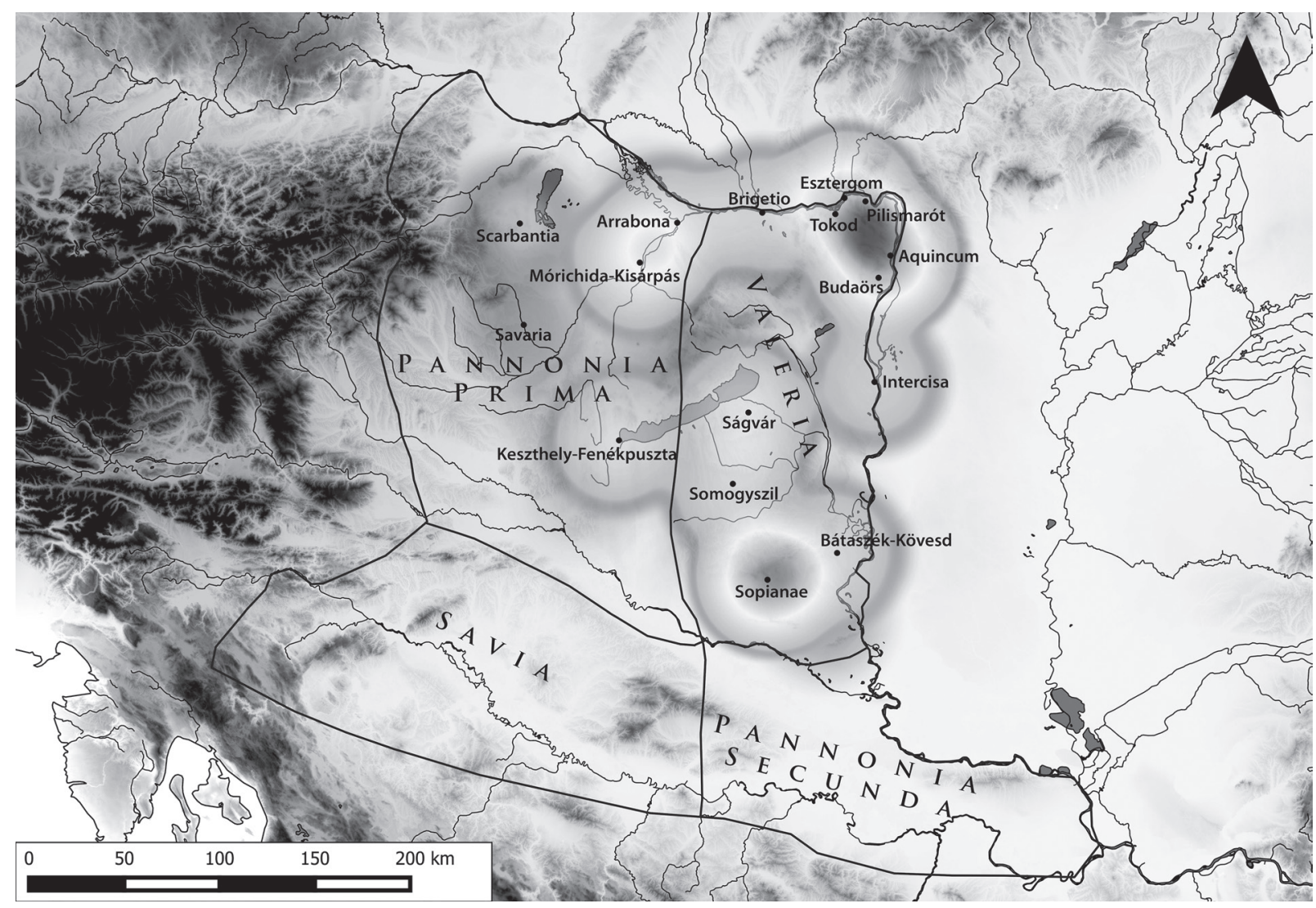

Fig. 11. Distribution of drinking vessels (made by L. Rupnik)

mentioned one example, housed in the Hungarian National Museum, which originates from an unknown place in Intercisa. This type of vessel spread across the area of the Sintana-de-Mures-Černjahov Culture, including presentday Ukraine, Romania and Bulgaria, where they might also have been manufactured. ${ }^{95}$ This type may be connected with the Goths, whose trading and wanderings contributed to its spread. These vessels were probably not locally produced, they were most likely imported goods. ${ }^{96}$

Tableware used for serving liquid was primarily used in bigger urban settlements and in villas from the $1^{\text {st }}$ century $\mathrm{AD}$ to the $3^{\text {rd }}$ century AD. ${ }^{97}$ This tendency remained dominant in the late Roman Period as this type of tableware is a typical find of urban settlements in Pannonia from the $4^{\text {th }}$ century AD. (Fig. 16). In the late Roman period their popularity increased in wealthy communities considerably and the form of the blown glass vessels reflected the chic silver jugs of the period. ${ }^{98}$ These jugs make up $10 \%$ of the studied vessels. ${ }^{99}$ Oil, French vinegar and other liquids are assumed to have been stored in the smaller variants, while bigger ones were suitable for serving wine. One of the simplest forms were the mainly glass green globular vessels (K 1), ${ }^{100}$ which were locally produced. Due to its relatively small size this type was not convenient for serving wine. This type existed from the first third of the $4^{\text {th }}$ century AD in Pannonia, and was widely used in the second half of the century. Strong yellow/ green versions of it still occurred during the first half of the $5^{\text {th }}$ century AD. ${ }^{101}$ A remarkably good quality green glass example with an indented body was uncovered in the cemetery on Szent Márton Street in Savaria. It probably

${ }^{95}$ STERN 2001, 333.

${ }^{96}$ PÁnCZÉL-DoBos 2007, 73

${ }^{97}$ VAN LITH-RANDSBORG 1988, 424-430.

${ }^{98}$ STERN 2001, 146.

${ }^{99}$ DÉVAI 2012, 173-180.
${ }^{100}$ BARKÓCZI 1988, Form 155,159, 160,169; RÜTTI 1991, Form 169; Goethert-PolascheK 1977, Form 117; CotTAM-Price 1998, Fig. 69, 73; LAZAR 2003, Form 5.1.3 and 5.1.8, 5.1.9; CoOLPrice 1995, 217, Abb. 13.4; Follmann-Schulz 1992, Kat. Nr. 195; FolLMANN-SChUlz 1989, 49, Abb. 3.18-20.

${ }^{101}$ DévaI 2012, 174-176, Kat. Nr. 473-496. 


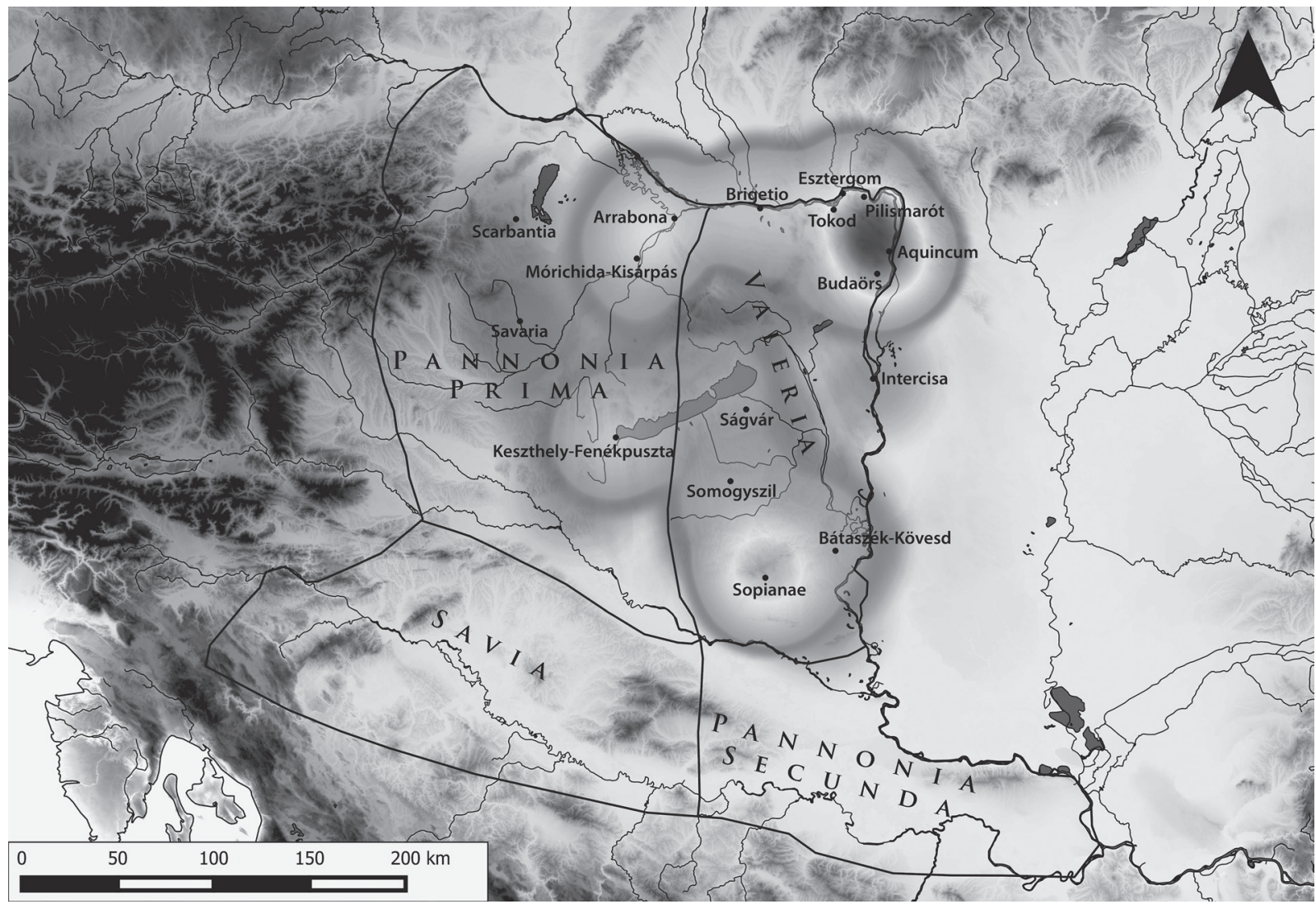

Fig. 12. Distribution of P1-P4 types (made by L. Rupnik)

originated from second third of the $4^{\text {th }}$ century $\mathrm{AD}$ and based on its craftsmanship, it might have been made in a workshop with high standards. A parallel to this particular jug was found in Brigetio. ${ }^{102}$

The cylindrical jugs (K 2) became popular after the first third of the $4^{\text {th }}$ century AD and they spread across the region in the second half of the century. ${ }^{103}$ The majority of these vessels are large, decorated glass-green or yellowish green vessels for serving liquids. They are decorated with single horizontal trails under the rim, and thin spiral trails on the neck. The jug found in Ságvár is unique because of the single horizontal trail under its rim, and because of its handles, both of which were made of translucent, dark blue glass. ${ }^{104}$ Dark blue trails and handles were applied to vessels in the Eastern part of the Imperium Romanum. ${ }^{105}$ The piece from Ságvár might have originated from this area. It was not produced locally. A jug from Aquincum is worth mentioning. ${ }^{106}$ This vessel stands out because the glass contains a purple stripe running in spirals on its neck and shoulders. It cannot be considered decoration since it is caused by manganese contamination in the raw material.

The final style of jug discussed in the study is the pear-shaped type (K 3), popular in the area that extended from the limes to the core of the Province. ${ }^{107}$ These jugs are made of naturally coloured glass, colourless glass, or yellowish green raw materials. These large, practical vessels appeared in the first half of the $4^{\text {th }}$ century AD and became most in the second half of the century. They were in used until the beginning of the $5^{\text {th }}$ century AD. This type of vessel, which resembles the elegant silver jugs of the period, was in commonly used throughout the Roman Empire. ${ }^{108}$ In the Eastern part of the Empire they were still fashionable in the $5^{\text {th }}$ century AD, while their production

102 BARKÓCZI 1988, 167.

${ }^{103}$ BARKÓCZI 1988, Form 154 and 168 b,c,d,e; RÜTTI 1991, Form 171; GoETHERT-POLASCHEK 1977, Form 125; IsINGS 1957, Form 126.

${ }^{104}$ Burger 1966, Grave 89; DÉvai 2012, Kat. Nr. 517.

${ }^{105}$ JenNINGs 2004-2005, 113, FIG. 5.27.5, 5.27.8.
${ }^{106}$ Inv. Nr.: 91.3.9; DÉVAI 2012, Kat. Nr. 504.

${ }^{107}$ BARKÓCZI 1988, Form 158 and 170, 173, 175, 176; RÜTTI 1991, Form 172; GOETHERT-POLASCHEK 1977, Form 124; ISINGS 1957, Form 120; CotTAM-Price 1998, Fig. 72; LAZAR 5.1.2.

${ }^{108}$ STERN 2001, 265. 


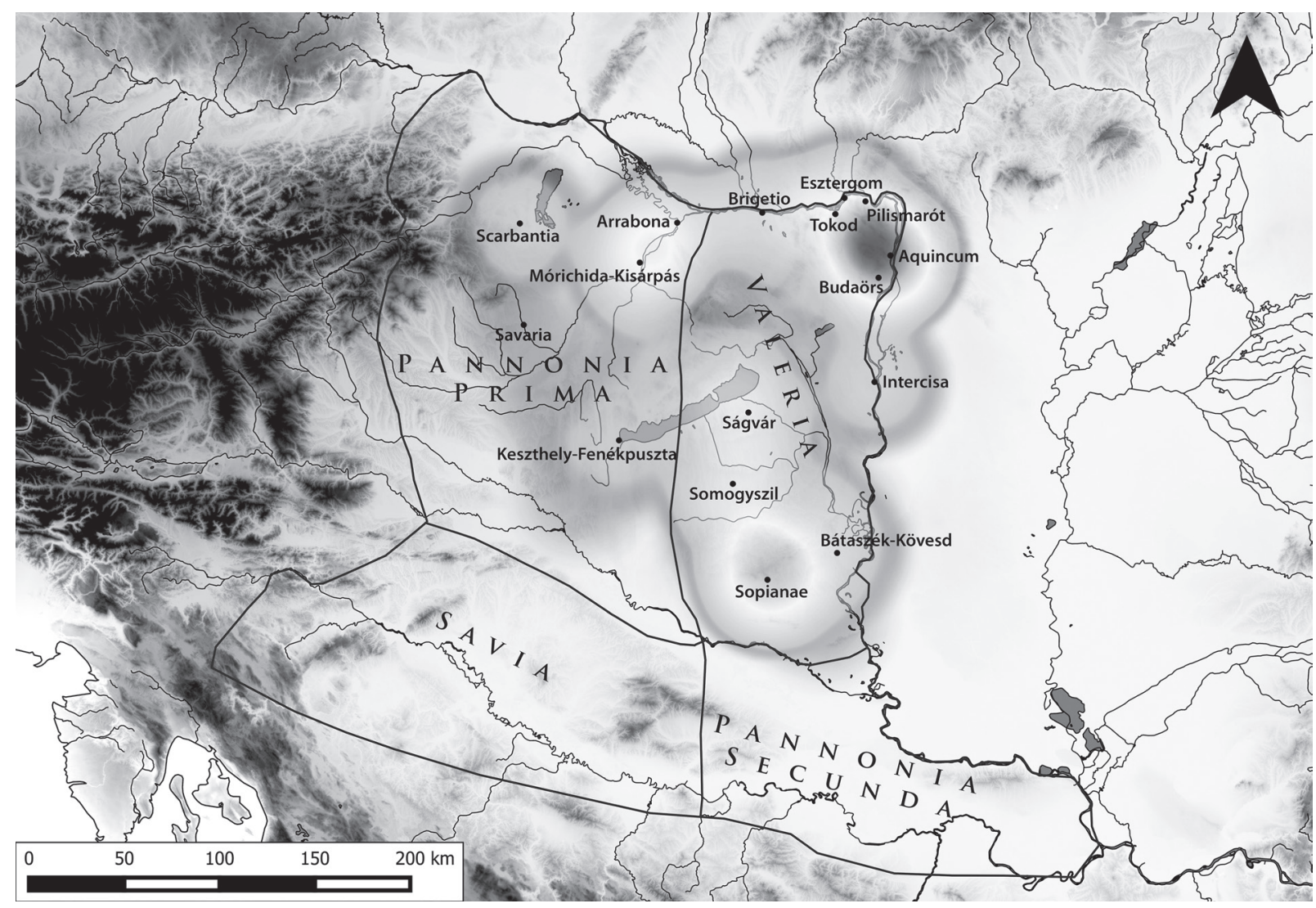

Fig. 13. Distribution of P5-P6 types of beakers (made by L. Rupnik)

was ceased earlier in the North-western provinces. ${ }^{109}$ Three-quarters of the Pannonian pear shaped jugs (K 3) are decorated. ${ }^{110}$ Three of them are unique. The translucent dark blue jug from Mosdós is remarkable. ${ }^{111}$ Diagonal ribs can be seen on the body of one of the jugs found in Brigetio. It was made by optic-blowing and its decoration omprises a spiral trail on the neck. These optic-blown ribs were particularly common in the North-western provinces, in North-Gallia, in Rhineland and in Pannonia. ${ }^{112}$ There is a piece from Pécs which is decorated with abrasion bands and facet-cut ovals. ${ }^{113}$ The jug from Mosdós was imported since the colour of its material was rare in the province. Some specimens were made of strongly coloured translucent glass known to originate from the general territory of the Empire.

Amongst storage and transport vessels, ones with a closed shape, used to store liquids, were found in outstanding numbers. They were represented by 200 pieces comprising $20.2 \%$ of the total number of vessels studied. ${ }^{114}$ These vessels without base rings were large, simple, and had little decoration. The ones with handles are thicker, less elegant, and less decorated than their counterparts that were used as tableware. Thick and wide ribbed ribbon handles characterize the transport and storage bottles. The possibility that these bottles served a secondary purpose as tableware must be taken into consideration. This is particularly true in the late Roman Period, when the increasing value of glass meant that less expensive and simpler vessels were frequently used as tableware. ${ }^{115}$

Half of the bottles, about one hundred examples, belong to the globular or discoid globular type (Pa 1). ${ }^{116}$ From the end of the $3^{\text {rd }}$ century AD to the middle of the $4^{\text {th }}$ century AD most bottles are simple, undecorated, colour-

${ }^{109}$ STERN 2001, 265.

${ }^{110}$ DÉVAI 2012, 178-179.

${ }^{111}$ BARKÓCZI 1988, 186, Kat. Nr. 486; DÉvAI 2012, Kat. Nr. 547

${ }^{112}$ FÜNFSCHILLING 1999, 87.

${ }^{113}$ DÉVAI 2012, Kat. Nr. 531. Paralell see: RuŽIĆ 1994, T. IX.3.

${ }^{114}$ DÉVAI 2012, 181
${ }^{115}$ FÜNFSCHILLING 1999, 79.

${ }^{116}$ DÉvai 2012, 181-184, Kat. Nr. 574-681; BARKÓcZI 1988, Form 118,119 and 123; RÜTTI 1991, Form 154; GoETHERTPOLASCHEK 1977, Form 93; IsIngS 1957, Form 103; LAZAR 2003, Form 6.2.1-3 and 6.2.6-7. 


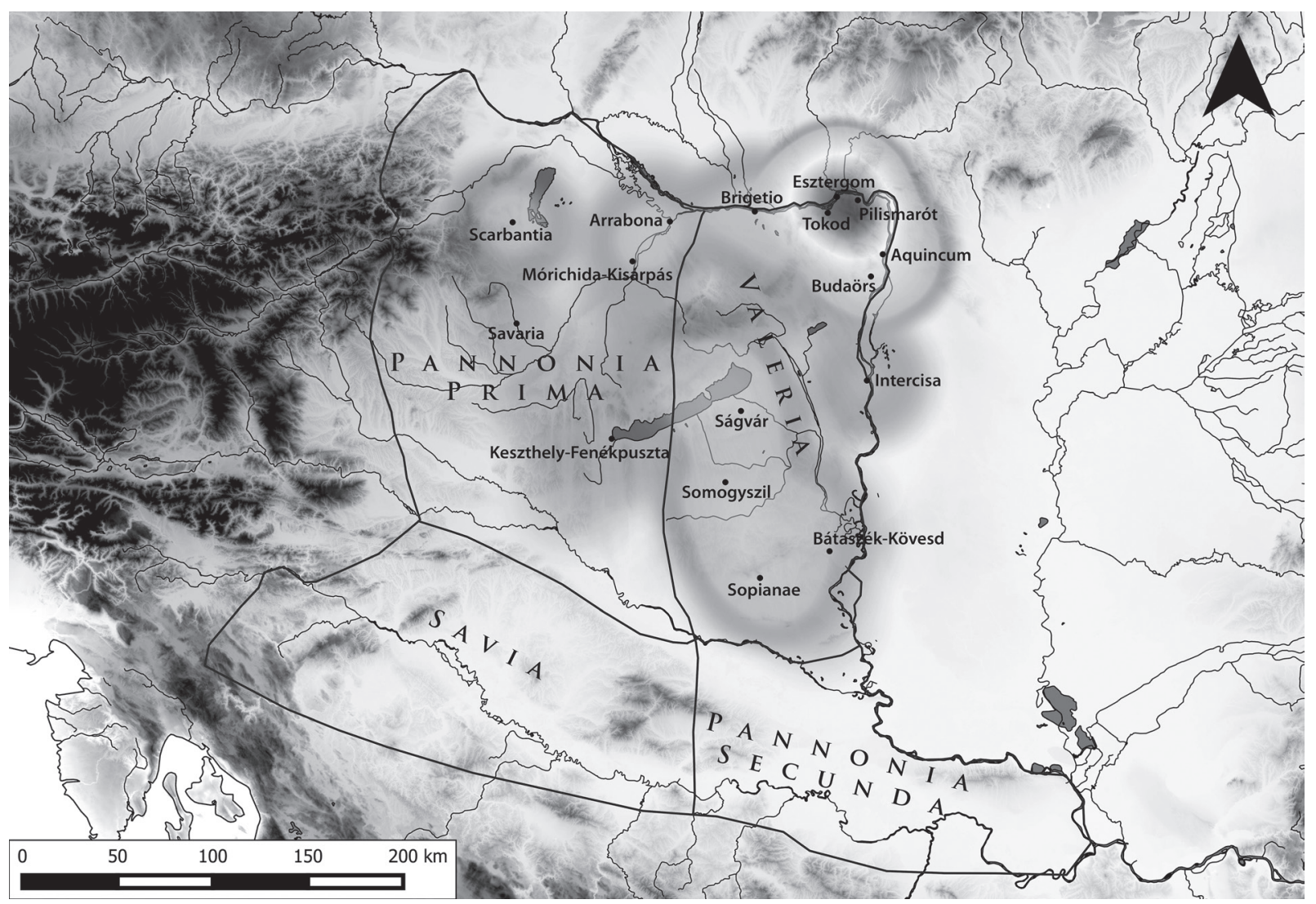

Fig. 14. Distribution of P7 types of beakers (made by L. Rupnik)

less or glassgreen shaded. Later in the $4^{\text {th }}$ century $\mathrm{AD}$ and the beginning of the $5^{\text {th }}$ century AD they are optic-blown yellowish green or dark green. They can be considered local products. The optic-blown ribbed version was not unfamiliar in the Eastern part of the Empire, although it was rather fashionable in the Western territories as well, including Pannonia, Noricum and Dalmatia. ${ }^{117} \mathrm{~A}$ bad quality, moss green bottle characterized by vertical ribs on its body from Sásd is unique. ${ }^{118}$ It has a sophisticated elaboration, which was popular in the Eastern part of the Roman Empire. Its counterpart was found in South-Pannonia. ${ }^{119}$ Similarly, globular bottles with funnel mouths (Pa 2) were local products as well. ${ }^{120}$ The spread of these bottles is similarly restricted in the case of the Pa 3 and Pa 4 types. ${ }^{121}$ The Pa 5 group,${ }^{122}$ which consists of cylindrical bottles with rounded shoulders, are simply elaborated local products. They frequently occurred along the limes. The polygonal bottles belonging to the $\mathrm{Pa} 6,7,8 \mathrm{forms}^{123}$ were represented by only a few examples from the late Roman period. Their attributes are different from earlier ones, suggesting they probably were not imported.

The Pa 9 type ${ }^{124}$ features large bottles, which spread across the Roman Empire from the Rhineland, though Pannonia to the North coast of the Black Sea, and on to Syria and Egypt. ${ }^{125}$ This form was never mass-produced.

${ }^{117}$ STERN 2001, 267.

${ }^{118}$ DÉVAI 2012, Kat. Nr. 664.

${ }^{119}$ RužIĆ 1994, T. VI.3; Šaranović-Svetek 1986, 79, Typ VI.7. Čalma, 4. cent.

${ }^{120}$ BARKÓCZI 1988, Form 121; IsINGS 1957, Form 104; LAZAR 2003, Form 6.2.8; DÉVAI 2012, Kat. Nr. 682-694.

${ }^{121}$ BARKÓCZI 1988, Kat. 305; LAZAR 2003, Form 6.2.4. and HARTER 1999, Form G27c.

${ }^{122}$ HARTER 1999, Form F3b.
${ }^{123}$ BARKÓCZI 1988, Form 167c; RÜTTI 1991, Form 156; Goethert-PolascheK 1977, Form 114/119; IsINGS 1957, Form 50; LaZAR 2003, Form 6.3.2; CotTAM-Price 1998, Fig. 89.

BARKÓCZI 1988, Form 167 f; RÜTTI 1991, Form 158; Goethert-Polaschek 1977, Form 113; Lazar 2003, Form 6.3.3; CotTAM-Price 1998 Fig. 90.

BARKÓCZI 1988, Form 167g.

${ }^{124}$ BARKÓCZI 1988, 168 d,e; RÜTTI 1991, Form 171; GoETHERT-POLASCHEK 1977, Form 125; IsINGS 1957, Form 126; LAZAR 2003, Form 6.3.6; CotTAM-PRICE 1998 Fig. 92-93.

${ }^{125}$ FÜNFSCHILLING 1999, 86. 


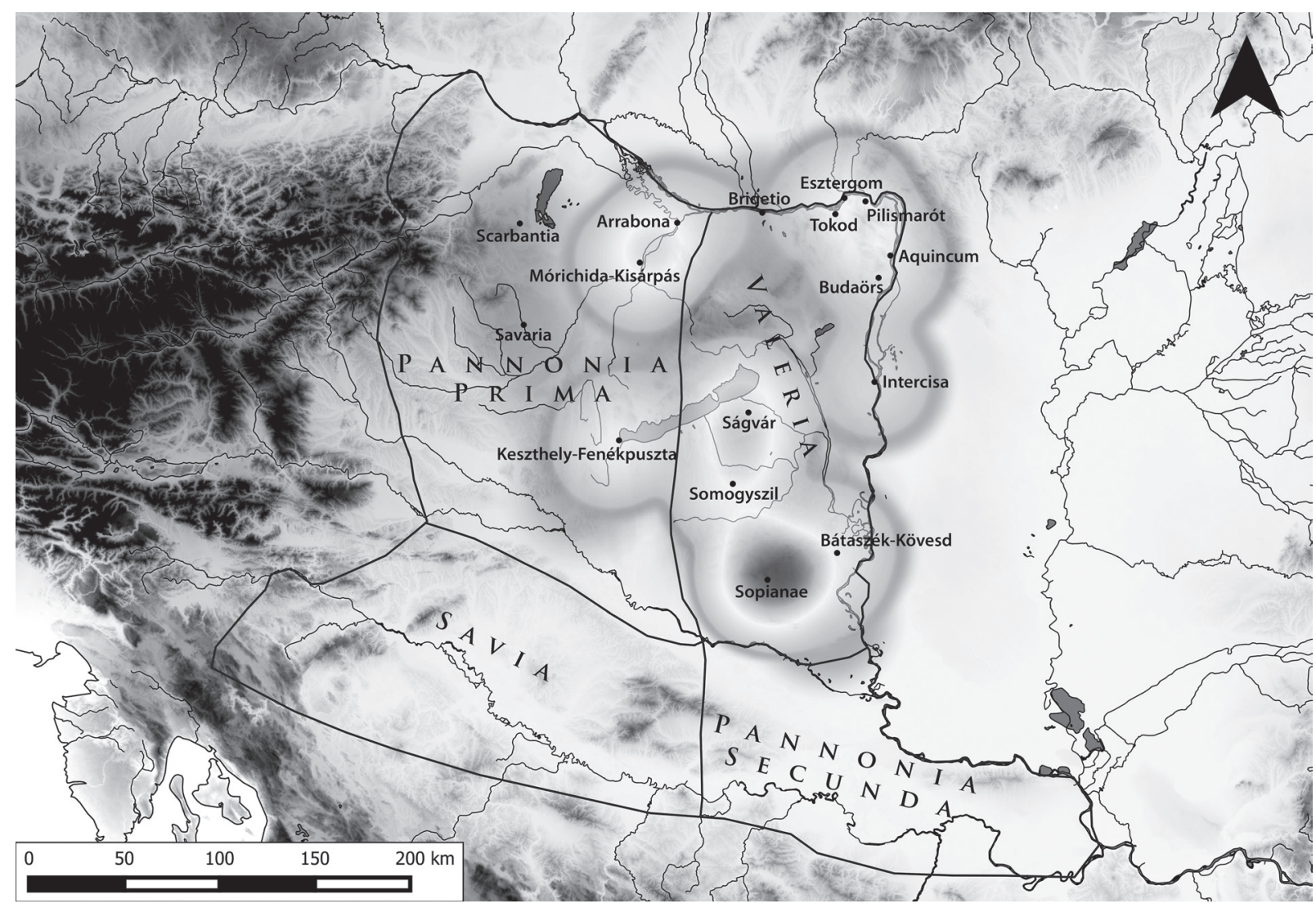

Fig. 15. Distribution of P8-P10 types of beakers (made by L. Rupnik)

Regardless of where they were found, these bottles are so similar that local variants cannot be differentiated. Their decorations might have been completed in workshops specialized in cut embellishments that were located far away from the blowing centres where the vessels were produced. Due to the time-consuming decoration method, these bottles were precious and embellished by masters specialized in wheel cutting. ${ }^{126}$ They were luxury items often found in graves which contained vas diatretum, or bottles decorated with gold leaf. ${ }^{127}$ Although these surface cuts appear on several objects, they can mainly be observed on cups and cylindrical bottles. The thick, dark green vessels existed in great amounts in Pannonia and probably were local products. ${ }^{128}$ Based on their occurrence they might have been produced in Northern France and Rhineland. ${ }^{129}$ They were popular because they were filled up with a certain liquid.

The amphora with base knob ( $\mathrm{Pa} \mathrm{10)}$ is decorated with a blue opaque single horizontal trail under the rim and handles, and is made of a strong yellowish-green glass. ${ }^{130}$ Its body is divided into three spheres, which are covered with abrasion lines and a cell shaped facet-cut pattern. Its volumetric capacity is that of two roman amphorae. ${ }^{131}$ The form imitating the classical ceramic transport vessels became popular in the late Roman period. Based on their decoration they might have been used to serve liquids. M. Stern, who classified these glass amphorae, categorized them into four main types. ${ }^{132}$ The above-mentioned object belongs to her 4.A.1.b type, and in Barkóczi's catalogue it is the 184.d variant. This type, which is frequently yellowish-green with dark-blue handles and applied trails on the neck, probably has Syrian origins. ${ }^{133}$ This amphora has two parallels. One of them is identical in shape

${ }^{126}$ STERN 2001, 138.

${ }^{127}$ STERN 2001, 138; FREMERSDORF 1967, 147-155.

${ }^{128}$ STERN 2001, 138.

${ }^{129}$ FÜNFSCHILLING 1999, 86.

${ }^{130}$ BARKÓCZI 1988, Form 184d, paralell see: RuŽÍ́ 1994,
${ }^{131}$ DÉVAI 2012, 238. The volumetric capacity of the amphora from Győrújbarát (Inv. Nr. 53.216.9) is $2652,4 \mathrm{~cm}^{3}$, which is 2 Roman amphora (1 amphora $\left.=1313,28 \mathrm{~cm}^{3}\right)$.

${ }^{132}$ STERN 1977, 84-85, Fig. 2-4

${ }^{133}$ STERN 1977, 84-85.

T. XIV.3. 


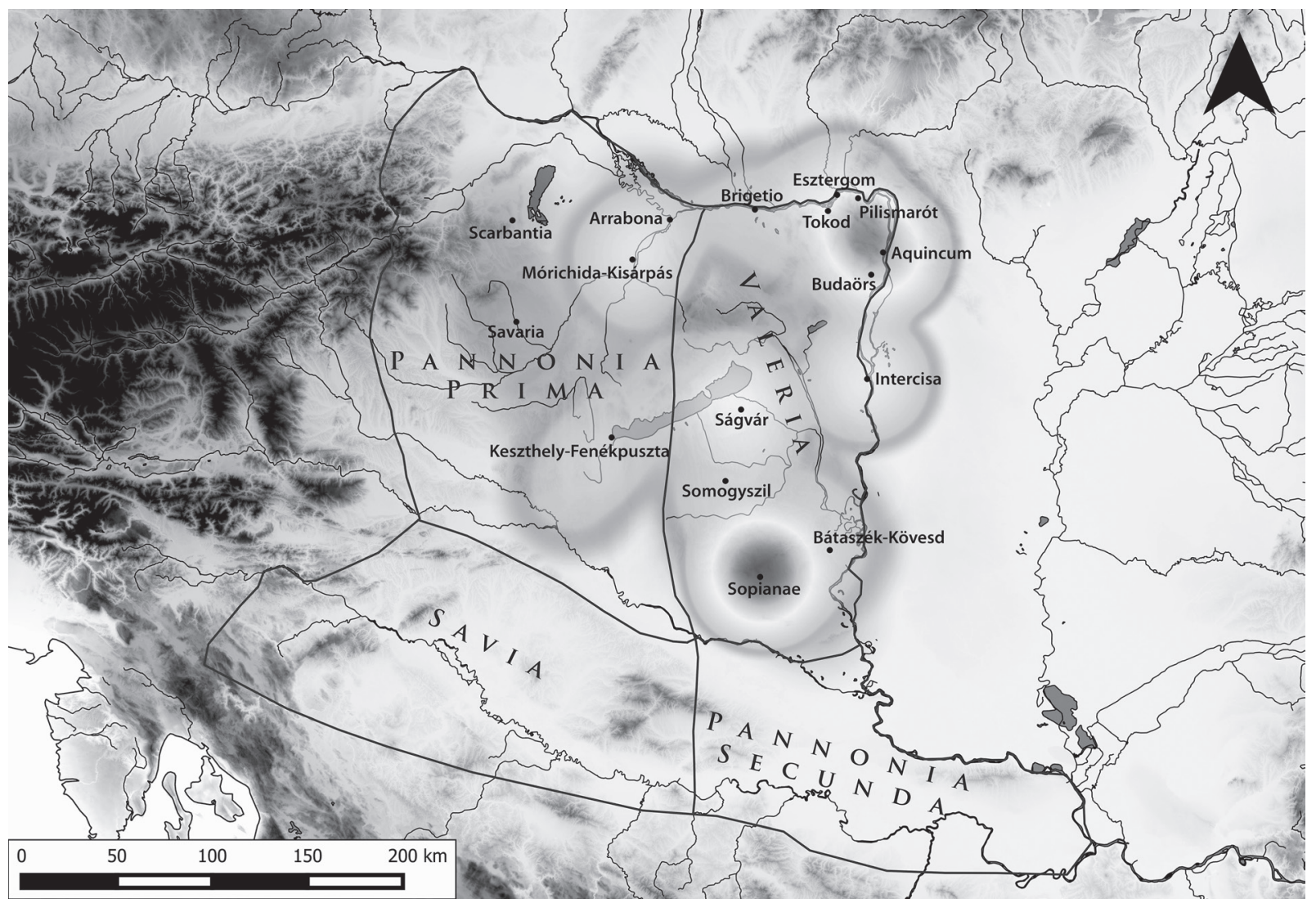

Fig. 16. Distribution of jugs (made by L. Rupnik)

and colour and was found in Scupi's Eastern cemetery ${ }^{134}$ The other one is decorated in a similar fashion and is exhibited in the Corning Museum. ${ }^{135}$ The globular amphora with a base ring (Pa 11) was made by optic-blowing and has an opaque dark blue base and handles. ${ }^{136}$ It can be dated back to the first half of the $4^{\text {th }}$ century AD. This corresponds to Stern's I.B.3. type, which is from an earlier period and also has Syrian origins. ${ }^{137}$ Its volumetric capacity is almost one Roman amphora. ${ }^{138}$ Thus these two atypical vessels were either imported or represent the personal belongings of individuals who moved to Pannonia.

The proportion of late Roman unguentariae decreased in comparison with the previous centuries, however they remained an outstanding group. All together $19 \%$ of all vessels found in Pannonia were unguentariae, ${ }^{139}$ similarly to the recorded quantity of $20 \%$ in Germania. ${ }^{140}$ Considering the variations of forms and sizes, this group of unguent bottles is the most diverse and comprises 21 different types of vessels. Based on about 200 identifiable fragments their their size ranges from tiny, 5 to 7 centimetres tall bottles to long, narrow pipette-shaped objects of up to 40 centimetres. Both globular bottles belonging to the I1 category, ${ }^{141}$ and globular bottles with a funnel mouth belonging to I 2 category ${ }^{142}$ spread across the province. They were simple, local products. Many types of unguent bottles are represented only by a single piece. Their forms were intriguing and they might have originated from outside the province. One such example is the I3 category, which includes one vessel from Ságvár. ${ }^{13}$ Its parallels are from South-Pannonia and Dalmatia. ${ }^{144}$ Likewise the types of I6-I12 are each represented by only one piece. The

\footnotetext{
${ }^{134}$ MikulČić 1974, 210. Tab. VIII.A-B.

${ }^{135}$ Witehaus 2001, 260, Kat. Nr. 445.

${ }^{136}$ DÉvaI 2012, Kat. Nr. 769

${ }^{137}$ STERN $1977,84-85$

${ }^{138}$ DÉvar 2012, 238. The volumetric capacity of the am-
} phora from Sopianae (Inv. Nr. 69.35.1) is $1201 \mathrm{~cm}^{3}$.

${ }^{139}$ DÉvAs 2012, 199-200.
${ }^{140}$ VAN LiTH-RANDSBORG 1988, 454.

${ }^{141}$ BARKóCZI 1988, Form 90; RÜTTI 1991, Form 146; LAZAR 2003, Form 8.6.15. and 8.6.16.

${ }^{142}$ RÜTTI 1991, Form 148; LAZAR 2003, Form 8.6.14.

${ }^{143}$ RÜTti 1991, Form 147.1; Goethert-PolascheK 1977, 


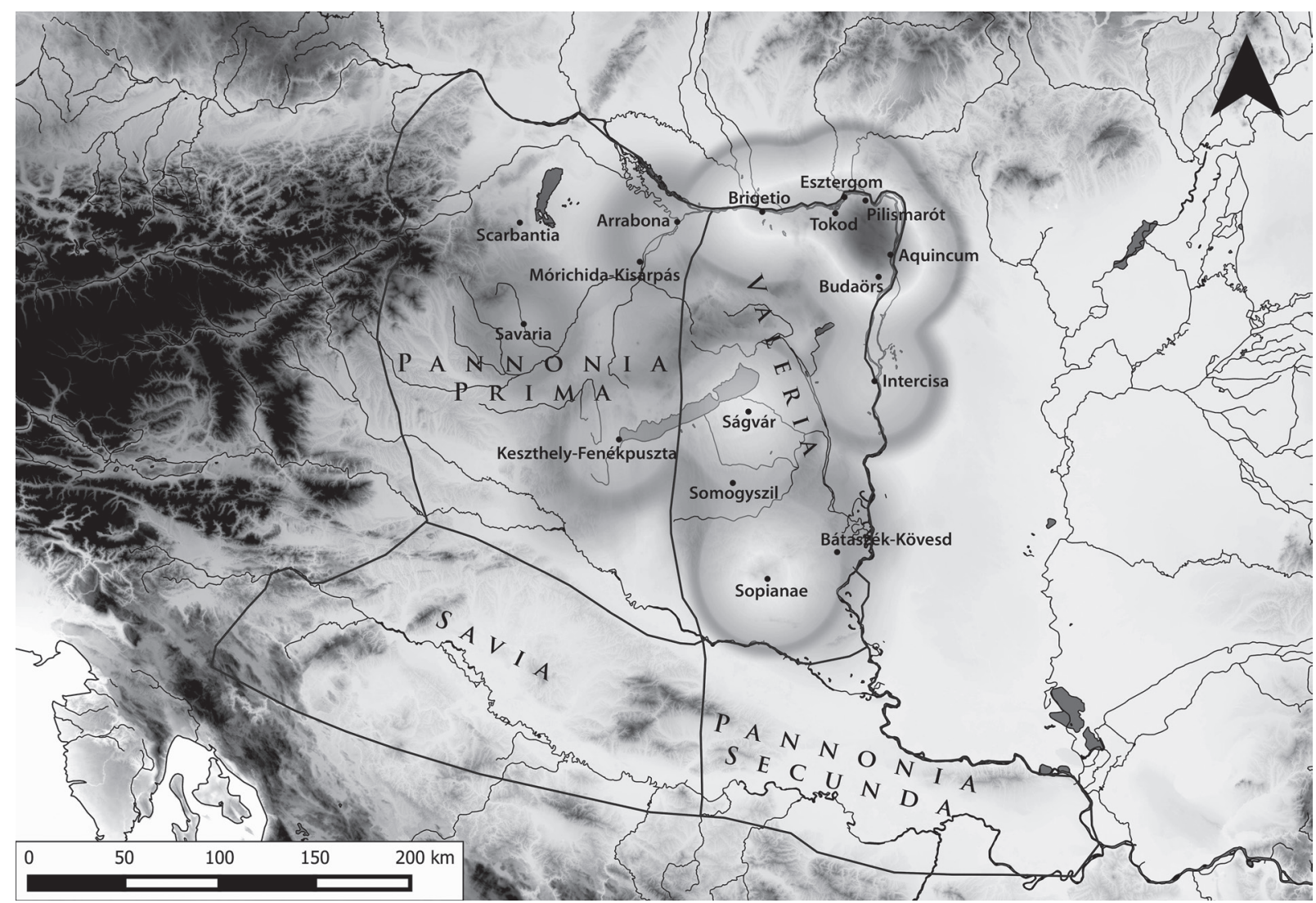

Fig. 17. Distribution of bottles (made by L. Rupnik)

I6-I11 forms consist of indented bottles, ${ }^{145}$ whereas the I 12 object has a simple cylindrical form and was probably a provincial product. The I 13 vessel is small and cylindrical with a wide mouth. It has double curved rims but no neck. This object has no known counterpart. The I 14 type is a hexagonal vessel which was found in Brigetio. Identical objects are known from the Southern part of Pannonia, which is part of modern-day Serbia. ${ }^{146}$ These variable but unique objects without known parallels outside the province were common in bigger urban settlements such as Sopianae, Ságvár, Brigetio, Aquincum. (Fig. 18).

The long, narrow, pipette-shaped unguent bottle forming the I 18 group was common in the late Roman Period. ${ }^{147}$ It has a smaller variant, found in children's graves and which is less typical, and a larger variant, whose height can reach up to 40 centimetres. One of the peculiar features of these asymmetrical, partially free-blown large vessels is that they were put on a pontil to complete their rims. For this reason, traces of glass drops that stuck to the pontils which might have been of a different raw material can be seen on their base. The fixing was colourless glass on a dark green pipette-shaped vessel from Pécs. A small piece of glass often breaks in a circle at the place of the pontil mark. This helps calculate the diameter of the pontils, which are usually about two centimetres in these cases. ${ }^{148}$ Due to their rounded bottom, these types of vessels could not stand on their own and wooden or metal holders were needed. In the course of my research 55 pieces were collected. This number proves the popularity of this type of

144 Šaranović-SveteK 1986, 81, Typ. IX.11; FADIĆ 2006, 63, Br. Kat. 86; Ravagnan 1994, 112, Cat. 209.

${ }^{145}$ GREGL-LAZAR 2008, 91; Dévai 2012, form I 6-7 and I 11: no paralells; Form I 8: RUŽIć 1994, T. XXII.7; RÜTTI 1991, Form 147.2; GOETHERT-POLASCHEK 1977, Form 78; Form I 9: BARKÓCZI 1988, Form 97; BARKóCZI 1988, 123; GRegl-LAZAR 2008, 91, Pl. 21.2; Fadić 2006, 48, Br. Kat. 52; Avellier-Dulong-NenNa 2005,
405, Kat. Nr. 1107; Form I 10: RuŽÍć 1994, T. III/10b; RÜTTI 1991, Form 147.2; GoETHERT-PolascheK 1977, Form 78

${ }^{146}$ RUŽIĆ 1994, T. XXII.5.

${ }^{147}$ BARKÓCZI 1988, Form 103; IsINGS 1957, Form 105; Goethert-PolascheK 1977, Form 85; Harter 1999, Form D18b; COOL-Price 1995, Fig. 86.

${ }^{148}$ DÉVAI 2012, 206-207. 


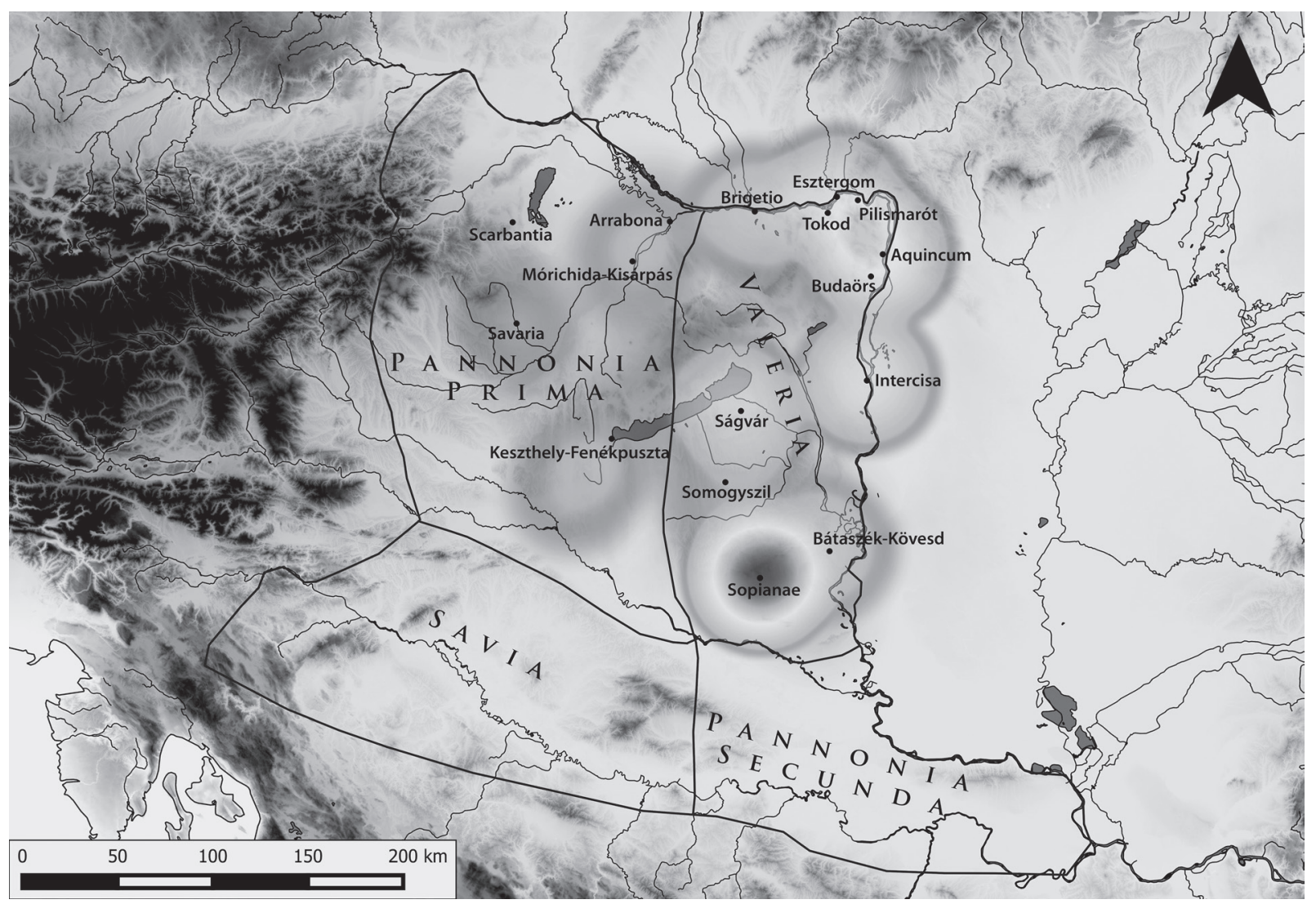

Fig. 18. Distribution of unguentariae (made by L. Rupnik)

object in late Roman Pannonia, mainly in urban settlements. ${ }^{149}$ Their colours vary. Earlier vessels were glass-green or colourless, whereas later ones were dark green, yellowish green or moss green. This type spread across the Roman Empire, and it is a recurrent find in the Northern provinces. ${ }^{150}$ They appeared in the $3^{\text {rd }}$ century $\mathrm{AD}$ and they were still in use at the beginning of the 5th century AD. They were used to store unguentum, oil and creams. The earlier versions of this type were larger, but by the end of the $4^{\text {th }}$ century AD they became slimmer. According to $\mathrm{U}$. Friedhoff the long, narrow, pipette shaped bottles can be associated with funeral services. They contained liquids, wine, liniments, oils, and scented creams, which were used during such ceremonies. ${ }^{151}$ They were placed either next to the shins or next to the head of the deceased. ${ }^{152}$

The I 19 form is a hollow bulb without rims or a neck. ${ }^{153}$ The only specimen of this type was found in Pécs. It was probably used for a long time by inheritance. Although impossible to verify, this special piece may have been produced in the second half of the $2^{\text {nd }}$ century $\mathrm{AD}$, although it was found in a late Roman grave. ${ }^{154}$ It was free-blown with a thick body made from dark blue, opaque glass. ${ }^{155}$ It was not manufactured locally. In the $4^{\text {th }}$ century AD the aryballoi forming the I 20 category occurred only sporadically. ${ }^{156}$ One example decorated with trails originates from Ságvár, from the second half of the $4^{\text {th }}$ century $\mathrm{AD} .{ }^{157}$ It is most likely an imported product.

${ }^{149}$ DÉVAI 2012, Kat. Nr. 888-941.

${ }^{150}$ Foy 1995, 192, 220; FoY-HoChULI-GYSEL 1995, 159, Fig. 12; Harter 1999, 102; Pirling 1966, Typ. 219, GoetherPolascheK 1977, Kat. 351, Typ. 85; Follmann-Schulz 1989, Nr. 14., 49; FRIEDHOFF 1999, 151.

${ }^{151}$ FrIEDHOFF 1999, 151, 157.
${ }^{152}$ HARTER 1999, 103.

${ }^{153}$ DÉVAI 2012, Kat. Nr. 942.
${ }^{154}$ Baggio Simona 1991, 120, Taf. 13; Follmann-SchulZ 1992, 91-92; ISINGS 1957, 26; HARTER 1999, 87.

${ }^{155}$ RÜTTI 1991, Form 124; IsINGS 1957, Form 10.

${ }^{156}$ RÜTTI 1991, Form 151; IsINGS 1957, Form 61; GOETHERT-PolascheK 1977, Form 135.

${ }^{157}$ Burger 1966, Grave 225; DéVAI 2012, Kat. Nr. 943; paralell see: BONNET BoREL 1997, 48. 
The last groups consist of miscellaneous vessels (Fig. 7). The E1 form, which is a spherical object ending in a knob is a curiosity. The only example from Pannonia was found in a man's in Bátaszék-Kövesd. ${ }^{158}$ This type of vessel was common in the Eastern part of the Empire beginning in the $5^{\text {th }}$ century $\mathrm{AD}$. It also appeared as a lantern in a fresco from Serdica. ${ }^{159}$ Two identical pieces, similar in shape and size, were found in Slovenia, one in Rodik and one in Kranj, at the site of a late antique glass workshop. Both items are decorated in a similar manner. ${ }^{160}$ Further parallels were found in Emona, Split, Jalame and Serbian Obrenovac, whose height was 7.8 centimetres. ${ }^{161}$ Some other counterparts were uncovered in Sardis in an early byzantine context, and in Rome dating to the $5^{\text {th }}$ century AD. ${ }^{162}$ The E 1 type was probably used as lamps, much like the P10 type conical cups with rounded bases, whose occurrence was rare and which differed from the fashionable conical drinking vessels both in their size and elaboration. ${ }^{163}$ According to dating done by Zs. V. Péterfi, the spherical object from Bátaszék-Kövesd was a remarkably early example. ${ }^{164}$ That said, the majority of this find's parallels were commonly used in the second half of the $5^{\text {th }}$ century AD.

The E 2 type objects are animal shaped vessels, which are represented by one find from Majs, dating to the late Roman Period (Fig. 7). ${ }^{165}$ It was an imported product and was decorated with trails.

The $\mathrm{E} 3$ form includes small vessels (12-15 cm high) with bodies reminiscent of amphorae (Fig. 7). They were elongated conical objects with a base knob and a funnel mouth. Since they did not have any handles, and the necks and rims were formed in a different manner they cannot be defined as amphorae. This group has two representatives, one from Pécs and one from Páty ${ }^{166}$ No other analogous finds are currently known. People might have consumed beverages from these vessels. They were similar to the late antique Sturzbechers as they featured base knobs and funnel-shaped mouths. On the other hand, they cannot be classified as cups due to the proportion of their shoulders. It is possible they were ungeunariae. Finally, it is worth mentioning that they may have served as lamps since they resemble early Islamic lamps both in their shape and presence of base knobs. That said, their funnelshaped mouth was not appropriate or practical for use as a lamp. Specifically, the specimen from Pécs features a tubular part inside its body, which suggests the vessel may have been hung.

The E 4 group consists of dripping flasks (Fig. 7) ${ }^{167}$ They were in use from the $1^{\text {st }}$ century AD to the $5^{\text {th }}$ century AD and spread across the Roman Empire. They were made from ceramic or glass, and their appearance reflects the form of the classical Greek guttus. ${ }^{168}$ The function of these objects is still debated. A theory from the $19^{\text {th }}$ century describes their function as nursing bottles to feed infants. ${ }^{169}$ The Hungarian archaeological literature describes their use only in this function. However, they might have contained oil, water, wine, medicine, or vinegar, they may have been produced for a variety of purposes. The vessel described by Varro was identical to this form, and was used to pour wine. ${ }^{170}$ If the function of these vessels was purely as nursing bottles, they should have been found exclusively in children's graves. In fact, in most cases they were uncovered next to men or women in adult graves. Another popular assumption is that lamp oil was kept in them. The glass versions could not fulfil this function due to their shape, elaboration and dropping tube. Since these shape and appearance of these objects had not changed much since the $5^{\text {th }}$ century $\mathrm{BC}$, their precise function cannot be determined due to lack of evidence. ${ }^{171}$ Twelve representatives from the late Roman Period have been collected. ${ }^{172}$ Most of them are glass green or colourless, and a few of them are yellowish green or moss green. The latter date to later periods. The quality of their raw materials varies. Most flasks were manufactured between the beginning of the $4^{\text {th }}$ century AD and the last third of the century, and then their occurrence was scare. Three of the later examples originated from Aquincum, Kisárpás and Pilismarót.

The E 5 category includes six small, jar-shaped vessels (Fig. 7). ${ }^{173}$ Three of them were uncovered in Aquincum, two in Pécs, and one in Esztergom, Bánomi-dűlő. The jar from Bánomi-dülő was situated next to one of

${ }^{158}$ PÉterfi 1993, 90-91, Grave 21.

${ }^{159}$ CROWFOOT-HARDEN 1931, 202.

${ }^{160}$ LAZAR 2003, 200-201; SAGAdin 2004, 113, Fig. 6.1.

${ }^{161}$ RuŽIĆ 1994, 56, Kat. 1189; LAZAR 2003, 201; JENNINGS 2004-2005, 146, Fig. 6.20.9.

${ }^{162}$ SALDERN 1980, 52, Typ. 4; STERNINI 1991, 122, Fig. 20.

${ }^{163}$ DÉVAI 2012, 210-211. The volumetric capacity is $127 \mathrm{~cm}^{3}$.

${ }^{164}$ PÉtefi 1993, 97.

${ }^{165}$ BARKÓCZI 1988, 215, Kat. Nr. 548.

${ }^{166}$ DÉvAI 2012, Kat. Nr. 966-967.
${ }^{167}$ LAZAR 2003, Form 10.2.2; HARTER 1999, Form G18b. South-Pannonia: RuŽIĆ 1994, T. XLI.2; Vindobona: SAKL-OBERTAHLER-TARCSAY 2001, 95, Taf. 4.42; Dalmatia: FADIĆ 1997, 204.

${ }^{168}$ SNIJDER 1933, 34.

${ }^{169}$ SNIJDER 1933-34, 37.

${ }^{170}$ Varro, De lingua Latina V.26.124.

${ }^{171}$ STERN 2001, 145.

${ }^{172}$ DÉvai 2012, Kat. Nr. 968-978.

173 RÜTTI 1991, Form 113; IsINGS 1957, Form 68; GoetherT-PolascheK 1977, Form 147d. 
Constantine's coins, which proves it was used in the $4^{\text {th }}$ century AD. ${ }^{174}$ These vessels were glass green or colourless, and made from good quality raw materials. Regarding their shape, they are similar to jars, but owing to their small size (height of 6-8 centimetres, diameter of rims of 3.7-7 cm) food could not be stored in them. A tubular indentation on the inside the vessels can be observed on several pieces. This deliberate indentation was not easily produced and it is possible that it served to suspend the vessel by threading a string or a chain through it. One example of the E 5 form was revealed along with a bronze spatula, which helped identify the small jarform as an unguentariae. ${ }^{175}$ Based on two examples of this type found in Trier, H. Cüppers assumed that they were used as a cupping-glass. ${ }^{176}$ Nonetheless, this hypothesis has not been proved. Most fragments of this type were uncovered in the insula where the women's bath was located in Augst. ${ }^{177}$ For this reason they probably served in healing activities or beauty care. Glass objects were frequently found in late Roman burials, the majority of them were beaker forms.

In the late Roman Period mould-blown glass made in single-piece moulds, multi-piece moulds, and optical blown vessels became fashionable. Most beakers were blown into single-piece moulds with the help of wooden forms. In other parts of the Roman Empire, optical blown beakers were favoured. These forms rarely appeared in Pannonia (Wabenbecher, beaker form from Mayen, beaker form from Rheinsheim). ${ }^{178}$ The studied material embodies 1000 objects out of which 453 were mould-blown drinking vessels. Until the last third of the $4^{\text {th }}$ century AD these beakers were colourless or glass-green, and made from good quality raw materials. By the end of the $4^{\text {th }}$ century $\mathrm{AD}$, and the beginning of the $5^{\text {th }}$ century $\mathrm{AD}$ they were mostly moss green or yellowish green, although the previously mentioned shades continued to be manufactured. At that time the raw materials were not refined and the final product was full of tiny bubbles and specks. Starting at the beginning of the $4^{\text {th }}$ century AD, cutting edge rims became common as a consequence of mould-blowing. These rims were refined by grinding until the end of the century. In most cases rims were only lightly smoothed or were left completely unworked, a trend that became dominant by the end of the century. One of the most important cupforms is the convex type with curved rim (halfegg shape). This $\mathrm{P} 7$ type comprises 67 pieces, out of which 36 cups are undecorated. ${ }^{179}$

Following the surrender of the province they remained fashionable in the Carpathian Basin during the $5^{\text {th }}$ century AD. Their production can be traced to Pannonia, because their quality and raw materials resemble the many undecorated or optical-blown globular bottles, cylindrical or pear-shaped jugs, and the smaller unguentariae found in the region. All of these objects might have been produced in workshops that were still operational in the $5^{\text {th }}$ century $\mathrm{AD}$, because their colours, forms, quality, rims, and decorations are the same as pieces from the end of the $4^{\text {th }}$ century $\mathrm{AD}$, and the beginning of the $5^{\text {th }}$ century AD. In terms of their territorial scattering, they are concentrated between Arrabona and Intercisa along the limes. Studying the regional division, two notable distribution regions can be highlighted from the second half of the $4^{\text {th }}$ century AD. One of them stretches from Arrabona to Intercisa along the limes. The most significant zone in this region is the Danube Bend owing to the huge number of glass vessels (53\% of the all objects) that were found here. The other crucial area is Sopianae and its surrounding area, with which $20 \%$ of glass vessels can be associated. These areas feature a wide range of forms, some of them unique finds from graves, whose parallels can be found throughout the Empire in the second half of the $5^{\text {th }}$ century AD. Due to the above-mentioned distributional theory, a few late Roman workshops in the areas surrounding Pécs and the Danube-bend most likely supplied these territories with vessels. ${ }^{180}$ According to L. Barkóczi's assumption, a workshop operated in Csákvár's Northern part. This hypothesis has not been proven yet. ${ }^{181}$

Finally, it is worth discussing a few interesting secondary use vessels. During the excavations under the number of 271 in Aquincum-Bécsi Street in 2007 T. Budai-Balogh uncovered two graves of children. In both cases separately blown bases of jugs were placed at children's feet. ${ }^{182}$ The other parts of these jugs were not found, although due to the thickness of the objects their rims and handles should have remained intact. On this type of base the underpart of the body was carefully cracked off. Although it remained unpolished it did not have sharp edges. When these base rings were turned over, they could replace beakers. The base rings of bigger jugs were suitable drinking devices for children, and could hold about 1 decilitre ${ }^{183}$ Presumably, the presence of these cups indicates a budget conscious solution. There are other similar graves in Pannonia. During the construction of the Graphisoft

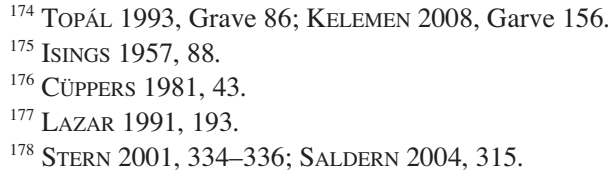

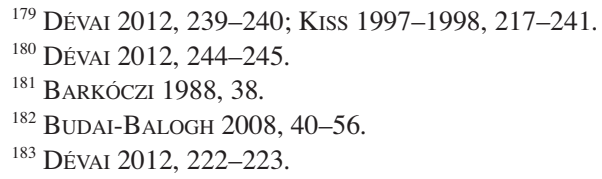

${ }^{179}$ DÉvaI 2012, 239-240; Kiss 1997-1998, 217-241.

${ }^{183}$ DÉVAI 2012, 222-223. 
Park near the Civil Town of Aquincum, G. Lassányi uncovered a separately blown foot with carefully cracked of edges. Furthermore, P. Zsidi found three more similar examples during the course of her excavations in KaszásdülöRaktárrét in the territory of Aquincum. ${ }^{184}$ This cheaper solution was possibly typical in Aquincum and its surrounding areas in the $4^{\text {th }}$ century AD. Apart from the above-mentioned find, K. Ottományi uncovered analogous examples in the cemetery of Budaörs. ${ }^{185}$ In order to properly observe and compare these findings, new well-documented excavations are needed. During earlier research only the most characteristic parts of vessels were preserved. In certain graves, thick and solid bases of long, narrow, pipette shaped unguent bottles can be found without any sharp edges on the body. These round, solid bottoms might have had a secondary use as stopper.

\section{CONCLUSION}

The period under discussion is the peak of glass production in Pannonia: there is a significant amount of very colourful and diverse glass finds, and there are whole series of vessels of most of the above mentioned types. ${ }^{186}$ The available material provides a perfect subject for a comparative analysis. Tall cups, flasks and jugs were the most common in this period, whereas storage and carrying vessels, and unguentariae were less typical. Raw materials were of good quality, and until the end of the $4^{\text {th }}$ century AD primarily colourless glass materials were used. The forms were simple and sophisticated with little decoration, however, certain parts were finely elaborated. In the middle of the $4^{\text {th }}$ century AD significant changes occurred, with regard to variations of popular forms and the combinations of different decorations. The quality of objects and the colour of glass materials became more diverse. Until the end of the $4^{\text {th }}$ century $\mathrm{AD}$ and the beginning of the $5^{\text {th }}$ century $\mathrm{AD}$ there was still a wide range of colourless glass vessels of good quality, however, the vast majority of objects were tableware and unguentariae, and were of bad quality, with dark specks and tiny bubbles, and with shades varying from dark green or moss green to yellowish green. The technology of production also changed as certain parts were not thoroughly refined - e.g. instead of polished and cracked-off rims, unpolished, roughly textured, unworked rims became more common.

Glass production in Pannonia was not over with the surrender of the province. The analysis of glass vessels found in cemeteries proves that Roman type glass vessels were produced until the end of the $5^{\text {th }}$ century AD (or at least until the middle of that century). By the end of the $5^{\text {th }}$ century the demand for glass objects diminished, as did the variety of shapes. From the second half of the $4^{\text {th }}$ century AD two regions can be highlighted with regard to the geographical distribution of glass vessels. The stretch of the limes between Arrabona and Intercisa, within the area of which the Danube Bend was the most remarkable one, as more than half of the vessels (53\%) were found in this region. The other zone was the city of Sopianae and its vicinity, where $20 \%$ of the studied glass finds were found (Fig 8).

\section{REFERENCES}

AvelLIER-DULONG-NENNA 2005

BAGGIO SiMONA 1991

BARKÓCZI 1960

BARKÓCZI 1968

BARKÓCZI 1988

BARKÓCZI 1990

BARKÓCZI-SALAMON 1968

BARKÓCZI-SALAMON 1970

\footnotetext{
= V. Arvellier-Dulong-M.-D. NenNA: Les verres antique du Musée du Louvre II. Vaiselle et contenants du $\mathrm{I}^{\mathrm{er}}$ siècle au debut du VII ${ }^{\mathrm{e}}$ siècle après J.-C. Paris 2005.

$=$ S. BAGgio Simona: I vetri romani. Provenienti dalle terre dell' attuale cantone Ticino. Locarno 1991.

= L. BARKóCZI: Későrómai temető Pilismaróton. FolArch 12 (1960) 111-130.

= L. BARKócZI: Die datierten Glasfunde aus dem 3.-4. Jahrhundert von Brigetio. FolArch 19 (1968) 59-86.

= L. BARKóczi: Pannonische Glasfunde in Ungarn. StudArch 9. Budapest 1988.

= L. BARKóczi: Üvegművesség. Glass. In: Pannonia régészeti kézikönyve. Ed.: A. Mócsy, J. Fitz. Budapest 1990, 151-166.

= L. BARKóCZI-Á. SALAMON: IV. század végi, V. század eleji üvegleletek Magyarországról. Glasfunde vom Ende des 4. and Anfang des 5. Jhs. in Ungarn. ArchÉrt 95 (1968) 29-39.

= L. BARKóCZI-Á. SALAmON: Bestattungen von Csákvár aus dem Ende des 4. und dem Anfang des 5. Jahrhunderts. AR 11 (1970) 35-76.
}

${ }^{184}$ ZSIDI 1984; ZSIDI 1987, 45-71

${ }^{186}$ BARKÓCZI 1988, 24-26.

${ }^{185}$ I'm very grateful to K. Ottományi, G. Lassányi and T.

Budai-Balogh for these unpublished datas. 
BONNET BOREL 1997

BudAI-BALOGH 2008

BURGER 1966

BURGER 1968

BURGER 1972

BURGER 1974

BuRgER 1979

COOL-Price 1995

CotTAM-Price 1998

CÜPPERS 1981

Crowfoot-HaRden 1931

DÉvaI 2012

DÉVAI 2012b

FADIĆ 1997

FADIĆ 2006

FOLLMANN-SCHULZ 1992

FolLMANN-SCHULZ 1989

FOY 1995

Foy-HochULI-GYSEL 1995

FREESTONE-GREENWOOD-

GorIN-Rosen 2002

\section{FREMERSDORF 1967}

FRIEDHOFF 1991

FÜLEP 1977

FÜLEP 1984

FÜNFSCHILLING 1999

ISINGS 1957

GÁBOR-KÁRPÁTI-KOVALICZKY-

POZSÁRKÓ-VISY 2003

GoETHERT-PoLASCHEK 1977

GREGL-LAZAR 2008

HARDEN 1936

HARTMANN-GRÜNEWALD 2010

HARTER 1999

HOFFMANN 2002

JENNINGS 2004-2005
= F. BONNET Borel: Le verre d'époque romiane à Avenches-Aventicum. Avenches 1997.

$=$ T. BUDAI-BALOGH: Beszámoló a katonaváros nyugati temetőjében végzett kutatásokról. Report on the investigations conducted in the western cemetery of the Military Town. AqFüz 14 (2008) 40-56.

= A. Sz. BuRger: The late Roman cemetery at Ságvár. ActaArchHung 18 (1966) 99-224.

= A. Sz. BuRgER: Későrómai sírok Halimbán Spätrömische Gräber in Halimba. FolArch 19 (1968) 87-98.

= A. Sz. BuRgER: Rómaikori temető Majson. Ein römerzeitliches Gräberfeld in Majs. ArchÉrt 99 (1972) 64-105.

= A. Sz. BuRgER: Rómaikori temető SomodorpusztánEin römerzeitliches Gräberfeld in SomodorPuszta (Szomor, Kom. Komárom).. ArchÉrt 101 (1974) 64-101.

= A. Sz. Burger: Das spätrömische Gräberfeld von Somogyszil. FontArchHung. Budapest 1979.

= H. M. E. CoOL-J. PRICE: Roman Vessel Glass from Excavations in Colchester, 1971-1985. CAR 8. Colchester 1995.

= S. CotTAM-J. Price: Romano-British Glass Vessels: A handbook. York 1998.

$=$ H. CRÜPPERS: Kranken- und Gesundheitspflege in Trier und dem Trierer Land von der Antike bis zur Neuzeit. Trier 1981.

= G. M. Crowfoot-D. B. HARden: Early Byzantine and later glass lamps. JEA 17 (1931) 196-208.

= K. DÉVAI: Késő római temetkezések üvegmellékletei Pannoniában. Pannoniában-Glass vessels from Late Roman times found in graves in the Hungarian part of Pannonia.[Manuscript, PhD thesis]. Budapest 2012.

= K. DÉVAI: A kúpostestű pohárforma funkcionalitásának kérdéséhez Questioning the function of conical glass cup and lamp in late Roman Pannonia. In: FIRKÁK II. Fiatal Római Koros Kutatók II. Konferenciakötete. Eds: Sz. Bíró, P. Vámos. Győr 2012, 261-267.

= I. FADIĆ: Il vetro, Transparenze imperiali. Vetri romani dalla Croazia. Milano 1997.

= I. FADIĆ: Argyruntum u odsjaju antičkog stakla-Argyruntum in the gleam of antique glass. Zadar 2006.

= A. B. FollmanN-SchUlZ: Die römischen Gläser im Rheinischen Landesmuseum Bonn. Köln 1992.

= A. B. Follmann-Schulz: Ein römischer Grabfund des 4. Jahrhunderts n. Chr. aus Zülpich-Enzen, Rheinland. KJb 22 (1989) 49-68.

= D. FoY: Le verre de la fin du IV ${ }^{\mathrm{e}}$ au VIII ${ }^{\mathrm{e}}$ siècle en France méditerranéenne, premier essai de typochronologie. AFAV 8 (1995) 187-242.

= D. Foy-A. Hochuli-Gysel: Le verre en Aquitaine du IV ${ }^{\mathrm{e}}$ au IX siècle, un état de la question. AFAV 8 (1995) 151-177.

= I. C. Freestone-R. Greenwood-Y. Gorin-Rosen: Byzantine and Early Islamic glassmaking in the Eastern Mediterranean. Production and distribution of primary glass. In: Hyalos Vitrum Glass. History, Technology and Conservation of Glass and vitreous Material in the Hellenic World. Ed.: G. Kordas. Athens 2002, 167-174.

= F. FREMERSDORF: Die römischen Gläser mit Schliff, Bemalung und Goldauflagen aus Köln. Die Denkmäler des römischen Köln 8. Köln 1967.

U. FRIEDHOFF: Der römische Friedhof an der Jakobstraße zu Köln. Kölner Forsch 3. Mainz 1991.

= F. FÜlEP: Roman Cemeteries on the Territory of Pécs (Sopianae). FontArchHung. Budapest 1977.

= F. FÜlEP: Sopianae. The History of Pécs during the Roman Era, and the Problem of the Continuity of the Late Roman Population. ArchHumg 50. Budapest 1984.

= S. FÜNFSCHILLING: Die geschlossene Form - Flaschen, Kannen, Krüge in spätrömischer Zeit. In: Römische Glaskunst und Wandmalerei. Red.: M. J. Klein. Mainz 1999, 78-90.

= C. IsINGs: Roman Glass. Groeningen/Djakarta 1957.

= O. GÁbor-G. Kárpáti-G. Kovaliczky-Cs. Pozsárkó-Zs. Visy: 19. Nemzetközi Limeskongresszus Pécs-Sopianae 2003. Örökségi füzetek 1. Pécs 2003.

= K. Goethert-PolascheK: Katalog der römischen Gläser des Rheinischen Landesmuseums Trier. Mainz am Rhein 1977.

= Z. Gregl-I. LaZAR: Bakar. Staklo iz rimske nekropole - The Glass from the Roman Cemetery. Zagreb 2008.

= D. B. HARdEN: Roman Glass from Karanis. Found by the University of Michigan Archaeological Expedition in Egypt, 1924-1929. Oxford 1936.

= S. Hartmann-M. Grünewald: The late Antique Glass from Mayen (Germany). First results of chemical and archaeological studies. In: Glass along the Silkroad from 200 BC to 1000 AD. Ed.: B. Zorn. Mainz 2010, 15-27.

= G. HARTER: Römishe Gläser des Landesmuseums Mainz. Wiesbaden 1999.

= B. HofFmanN: Römisches Glas aus Baden-Württemberg. Stuttgart 2002.

= S. JenNings: Vessel glass from Beirut. Bey 006, 007 and 045. Berytus 48-49 (2004-2005). 
KELEMEN 2008

KISS 1997-1998

KovÁCs 2007

LÁNYI 1972

LAZAR 2003

VAN LITH-RANDSBORG 1985

MIKULČIĆ 1974

OTTOMÁNYI 2001

PÁNCZÉL-DOBOS 2007

PERROT 1967

PÉREFI 1993

PIRLING 1966

PIRLING 1989

PIRLING 1979

RAVAGNAN 1994

RUŽIĆ 1994

RÜTTI 1991

SALDERN 1980

SALDERN 2004

SAGADIN 2004

SÁGI 1969

SAGUí 2007

SAKL-OBERTAHLER-TARCSAY 2001

ŠARANOVIĆ-SVETEK 1986

SCHMIDT 2000

SNIJDER 1933

STRAUME 1987

STERN 1977

STREN 2001

STERN 1995

STERNINI 1991

SZIRMAI 1975

SZŐNYI 1979

TOPÁL 1993
= M. H. KeLEMEN: Solva. Esztergom későrómai temetői. die spätrömischen Gräberfelder von Esztergom. Libelli archaeologici Ser. N. 3. Budapest 2008.

= A. Kiss: Glasfunde aus Gräbern des frühmittelalterlichen Karpatenbeckens (400-1000). Antaeus 24 (1997-1998) 217-241.

= P. KovÁcs (ed.): Corpus Inscriptionum Graecarum Pannonicarum. Hungarian polis studies 15. Budapest 2007.

= V. LÁNYI: Die spätrömische Gräberfelder von Pannonien. ActaArchHung 24 (1972) 53-213.

= I. LAZAR: Rimsko Steklo Slovenije - The Roman Glass of Slovenia. Ljubljana 2003.

= S. M. E. VAN Lith-K. RANDSBorG: Roman glass in the West. A social study. BROB 35 (1985) 413-533.

= I. Mikulčıć: Antičko staklo iz Scupi-a i ostali Makedonski nalazi - Ancient glass from the east necropolis of Scupi. AV 25 (1974) 191-210.

= K. OTTOMÁNYI: „Hunkori” sírok a pátyi temetőben. „Hunnenzeitliche” Gräber im Gräberfeld von Páty. ArchÉrt 126 (2001) 35-74

$=$ Sz. PÁnCZÉL-A. Dobos: Facet cut glass vessels of the late $3^{\text {rd }}$ to the $5^{\text {th }}$ century A.D. Analysis of find from North Danubian Romania. In: Funerary Offerings and Votive Depositions in Europe's 1st Millenium A.D. Cultural Artefacts and Local Identities. Ed.: C. Cosma. Cluj-Napoca 2007, 67-97.

= P. N. PerRot: Recent important Acquisitions. JGS 9 (1967) 133-143.

= Zs. V. PÉTERFI: A Bátaszék-Kövesd pusztai későrómai temető. Der spätrömische Friedhof von Bátaszék-Kövesd puszta. WMMÉ 18 (1993) 47-168.

$=$ R. PIRLING: Das römisch-fränkische Gräberfeld von Krefeld-Gellep. Germanische Denkmäler der Völkerwanderungszeit. Serie B: Die fränkischen Altertümer des Rheinlandes 2. Berlin 1966.

= R. PIRLING: Das römisch-fränkische Gräberfeld von Krefeld-Gellep 1966-1974. Germanische Denkmäler der Völkerwanderungszeit. Serie B: Die fränkischen Altertümer des Rheinlandes 13. Stuttgart 1989.

= R. PIRLING: Vom römischen zum fränkischen Glas - Im Spiegel der Funde von Krefeld-Gellep. Annales AIHV 8. Liège 1981, 115-131.

= G. L. Ravagnan: Vetri antichi del Museo Vetrario di Murano. Corpus delle Collezioni del Vetro nel Veneto 1. Murano 1994

= M. RuŽıć: Rimsko staklo u Srbiji. Roman Glass in Serbia. Centar za arheološka istraživanja 13. Beograd 1994

= B. RÜTTI: Die römischen Gläser aus Augst und Kaiseraugst. FiA 13. Augst 1991.

= A. VON SALDERN: Ancient and Byzantine Glass from Sardis. London 1980.

= A. von SALDERN: Antikes Glas. Handbuch der Archäologie. München 2004.

= M. SAGAdiN: Poznoantična steklarska delavnica (?) v Kranju. Late antique glass workshop in Kranj. In: Drobci Antičnega Stekla - Fragments of Ancient Glass. Ed.: I. Lazar. Koper 2004, 107-114.

= K. SÁGI : Keszthely-Gátidomb. RégFüz 22 (1969) 31.

= L. SAGUi: Glass in Late Antiquity. The contiunity of technology and sources of supply. In: Technology in Transition. A. D. 300-650. Eds: L. Lavan, E. Zanni. Leiden-Boston 2007, 211-231.

= S. SAKL-OBERTHALER-K. TARCSAY: Römische Glasformen aus Wien. Fundort Wien. Berichte zur Archäologie 4 (2001) 78-112.

= V. ŠARANOviĆ-SVETEK: Antičko staklo u Jugoslovenskom delu provincije donje PanonijeRömisches Glas aus dem jugoslawischen Gebiet der Provinz Pannonia inferior. Novi Sad 1986.

= W. SchmidT: Spätantike Gräberfelder in den Nordprovinzen des Römischen Reiches und das Aufkommen Christlichen Bestattungsbrauchtums. Tricciana (Ságvár) in der Provinz Valeria. SJ 50 (2000) 290-439.

= G. A. S. SniJder: Guttus und Verwandtes. Mnemosyne 1/1 (1933-1934) 34-60.

= E. StRAume: Gläser mit Facettenschliff aus skandinavischen Gräbern des 4. und 5. Jahrhunderts n. Chr. Oslo 1987.

= E. M. Stern: Ancient Glass at the Fondation Custodia (Collection Frits Lugt) Paris. Archaeologica Traiectina 12. Groningen 1977.

= E. M STERN: Römisches, byzantinisches und frühmittelalterliches Glas. 10 v. Chr. -700 n. Chr. Sammlung Ernesto Wolf. [S.1.] 2001.

= E. M. Stern: Roman Mould-Blown Glass. The first throught sixth centuries. Toledo 1995.

= M. STERNINI: Verres tradifs de Rome. Annales AIHV 12. Amsterdam 1993, 121-128.

= K. SzIRMAI: A Vihar utcai sírleletDer Grabfund aus der Vihar-Straße. ArchÉrt 102 (1975) 77-83.

= E. T. SzŐNYI: Arrabona késő római temetői. I: Vasútállomás környéki temető. Arrabona 21 (1979) $5-57$.

= J. TopÁL: Roman Cemeteries of Aquincum, Pannonia. The Western Cemetery, Bécsi Road I. Budapest 1993 
TOPÁL 2003

VÁGÓ-BÓNA

VESSBERG 1952

WhiteHOUSE 2001

ZSIDI 1984

ZSIDI 1987

ZSIDI 2005
= J. TopÁL: Roman Cemeteries of Aquincum, Pannonia. The Western Cemetery, Bécsi Road II. Budapest 2003.

= E. B. VÁGÓ-I. BóNA: Die Gräberfelder von Intercisa. 1: Der spätrömische Südostfriedhof. Budapest 1976.

= O. VessBerg: Roman glass in Cyprus. OpArch 7 (1952) 109-161.

= D. Whitehouse: Roman Glass in the Corning Museum of Glass. 2. New York 2001.

= P. Zsidi: A Kaszás Dülö-Raktárréti római kori temető elemzése. Analysis of the Roman cemetery in Kaszás Dülő-Raktárrét. Budapest 1984. [Diss. Manuscript.]

= P. ZsIDI: A Budapest XI. kerületi Gazdagréten feltárt 4-5. századi temető - Das auf dem Gazdagrét (Budapest XI., Bez.) erschlossene Gräberfeld aus dem 4-5. Jahrhunder. ComArchHung 1987, 45-71.

= P. ZsIDI (ed.): Kincsek a város alatt. Budapest régészeti örökségének feltárása, 1989-2004. Kiállítás a Budapesti Történeti Múzeumban 2004. május 27-augusztus 20. - Treasures under the City. Survey of the archaeological heritage of Budapest, 1989-2004. Temporary exhibition at the Budapest History Museum. Budapest 2005. 